\title{
Strategies for reducing inequalities and improving developmental outcomes for young children in low-income and middle-income countries
}

Patrice L Engle, Lia C H Fernald, Harold Alderman, Jere Behrman, Chloe O'Gara, Aisha Yousafzai, Meena Cabral de Mello, Melissa Hidrobo, Nurper Ulkuer, Ilgi Ertem, Selim Iltus, and the Global Child Development Steering Group

This report is the second in a Series on early child development in low-income and middle-income countries and assesses the effectiveness of early child development interventions, such as parenting support and preschool enrolment. The evidence reviewed suggests that early child development can be improved through these interventions, with effects greater for programmes of higher quality and for the most vulnerable children. Other promising interventions for the promotion of early child development include children's educational media, interventions with children at high risk, and combining the promotion of early child development with conditional cash transfer programmes. Effective investments in early child development have the potential to reduce inequalities perpetuated by poverty, poor nutrition, and restricted learning opportunities. A simulation model of the potential long-term economic effects of increasing preschool enrolment to $25 \%$ or $50 \%$ in every low-income and middle-income country showed a benefit-to-cost ratio ranging from 6.4 to $17 \cdot 6$, depending on preschool enrolment rate and discount rate.

\section{Introduction}

This report, the second in a Series, assesses the effectiveness of early child development intervention programmes in low-income and middle-income countries, calculates the cost of not investing in early child development, and builds on the 2007 Series in The Lancet on child development. ${ }^{1-3}$ The first report ${ }^{4}$ of the present Series identified socialcultural, psychosocial, and biological risk and protective factors that affect child development. The theoretical framework used in both reports, presented in the first figure of the first report, illustrates how children's developmental trajectories are affected by biological systems and by positive and negative risk and protective factors. The intensity of these effects relates to the developmental periods in which the risk factors happen (timing), the dose or extent of the risks (exposure), and the child's individual reactivity (temperament) to the risk and protective factors. Effective programmes, policies, and other interventions can protect children from the negative consequences of living in poverty.

\section{Inequalities between and within countries}

Social and economic differences, both between and within countries, contribute to inequalities in children's development. The WHO Commission on the Social Determinants of Health, in a World Health Assembly report, ${ }^{5}$ highlighted the social injustice of "avoidable health inequalities" and concluded that social and economic policies addressing early child development can affect whether children develop to their potential or experience a constrained life-course trajectory. Not only are there major differences between countries in preschool attendance by gross national income (GNI), but also within countries.
Children in the highest income quintile in a particular country are more than twice as likely to attend preschool (figure 1) as those in the lowest quintile in the same country, and are also more likely to have higher quality stimulation in the home (figure 2), as measured by Family Care Indicators (methods for both figures described in panel 1). Similarly, children aged 5 years in the highest-income

\section{Key messages}

- Early childhood is the most effective and cost-efficient time to ensure that all children develop their full potential. The returns on investment in early child development are substantial.

- Reducing inequalities requires integrated interventions early in life that target the many risks to which vulnerable children are exposed.

- Parenting interventions and centre-based programmes can improve children's cognitive and social-emotional development and school readiness.

- Quality in early child development programmes can be maximised through design, curriculum, practise for parents, training for childcare workers, monitoring and assessment, governance, and supervision.

- Increasing preschool enrolment to $25 \%$ or $50 \%$ in each low-income and middle-income country would result in a benefit-to-cost ratio ranging from $6 \cdot 4$ to $17 \cdot 6$ depending on preschool enrolment rate and discount rate.

- Unless governments allocate more resources to quality early child development programmes for the poorest people in the population, economic disparities will continue and widen. 


\section{Search strategy and selection criteria}

In our systematic review, we searched databases including Psychinfo, PubMed, Google Scholar, Global Health, Econ Lit, ISI Web of Science, Academic Search Elite, the World Bank website, the UNICEF Evaluation Database, and the Brookings Institution website, and we used personal contacts to identify unpublished work in both English and Spanish. Our primary search was done between September, 2009, and December, 2010, and we limited our search to papers that had been published since July, 2006, when the previous review was completed. We also included earlier papers that had not been included in the 2007 review. Our goal was to identify assessments of effectiveness interventions and programmes that included psychosocial components such as child stimulation, responsive interaction, early education, or other social investments, usually in combination with health, nutritional, social safety net, or parent educational interventions. Except for the informal searches, the search for published work was done in English, and the terms used in the review for intervention type were "parenting", "preschool", "pre-primary", "early learning", "stimulation", "conditional cash transfer", "media", "television", "Sesame Street", "social investment", and "educational intervention", and the terms for outcome measures were "early child development", "cognition", "language", "behaviour", or "socio-emotional development". We only included studies that focused on children aged 0-5years that were undertaken in low-income or middle-income countries.

We defined selection criteria separately for effectiveness studies and for programme assessments. For effectiveness studies, we included only those with a comparison group that met the criteria for "moderate or strong quality" of design according to the McMaster University Effective Public Health Practice Project Quality Assessment Tool For Quantitative Studies. These quality ratings were made by at least two of the authors. All studies included in the review had to have either a randomised controlled design at the individual or cluster level, or a cohort analytic design, defined as an observational study design where groups are assembled according to whether or not exposure to the intervention has happened and study groups might be non-equivalent or not comparable on some feature that affects outcome. For a moderate rating, there should have been either initial equivalence of the two groups or statistical controls for at least $80 \%$ of potential confounders. Econometric methods acceptable for assessing causality were accepted here also. For programme assessments, the assessments of quality related primarily to meeting accuracy standards, and included reporting valid and reliable data, sound analytic designs and analyses, and explicit and justifiable interpretations and conclusions.

42 efficacy or effectiveness studies and programme assessments met these criteria for all interventions. Studies that were eliminated had small sample sizes (defined as $n<50$ ), did not include a psychosocial intervention, focused on children outside of the 0-5year age group, had been reviewed in the previous analysis, did not meet the moderate or accurate quality standard for research design, or used outcome measures that were not valid. To be included in our review, studies were required to have been published in a peer-reviewed journal, or be available online as a working paper-student theses were not included. Although the period of early child development is often defined as lasting until the transition to school (age 8 years) we focus on children aged $0-5$ years, which includes most children in learning programmes before school attendance.

quintile had language performance between 0.5 and 1.5 SDs higher than those in the lowest-income quintile (figure 3) in Ethiopia, India, Peru, and Vietnam (Young Lives Longitudinal Study; panel 1). ${ }^{8}$

\section{Early child development programmes The challenge of sustainable improvement}

Despite evidence of the potential effectiveness of interventions in early childhood, policy makers and planners are challenged by designing interventions that sustainably improve early child development at scale. ${ }^{9}$ In our previous review ${ }^{3}$ we reported that 18 of 20 early child development programmes in low-income and middleincome countries substantially affected early child development, with the largest effects in comprehensive programmes. Other recent reviews, ${ }^{10,11}$ which included high-income countries, identified benefits from early child development interventions, particularly those incorporating educational or stimulation components.

Our present systematic review (see search strategy) included 42 effectiveness trials and programme assessments of parenting support and education, preprimary or preschool centres, conditional cash transfer programmes, educational media for children, and interventions for children at high risk (panel 2 provides a summary of the main findings). The effectiveness trials met the public health standards of experimental design ${ }^{12}$ and content criteria. Programme assessments were measured with reference to programme evaluation standards. ${ }^{13}$ These assessments often used quasiexperimental or matched designs, post-test only designs, or controlled for confounding factors with statistical and econometric methods. The programme assessments are included because they provide unique information about programmes at scale when the standards of a high quality effectiveness trial might not be possible.

\section{Parenting and education support}

Parenting interventions promote parent-child interactions to improve responsiveness in feeding infants and young children; ${ }^{14,15}$ increase attachment; ${ }^{16,17}$ and encourage learning, book reading, play activities, ${ }^{15,18}$ positive discipline, ${ }^{19}$ and problem-solving related to children's development, care, and feeding. ${ }^{20}$ Parenting education and support are often delivered through home visits, community groups, regular clinic visits, media or in combination with other components.

15 assessments (11 effectiveness trials and four scaledup programmes) of parenting interventions met our criteria (table 1 and webappendix pp 1-6). Parenting interventions used home visits, primary health care visits, ${ }^{18,20,25,26}$ group sessions with caregivers, and a combination of group sessions, home visits, community activities, and primary health care and nutritional services. Seven interventions worked primarily with parents or caregivers ${ }^{15,20,2428}$ and eight worked with parents or caregivers and children together. ${ }^{14,16-19,21-23}$ All 15 interventions had defined curricula or key messages.

Substantial positive effects on child development were identified in all 11 effectiveness studies; nine on cognitive or social-emotional development, and two on parent knowledge, home stimulation, and learning activities with children, ${ }^{20,24}$ which are associated with child development. ${ }^{29}$ Effect sizes were larger for interventions that included both parent and child programmes (median 0.46, range $0.04-0.97$ ) than for parent-only 
programmes $(0 \cdot 12,0 \cdot 03-0 \cdot 34)$. In some cases, effects were greater for younger children compared with older children, ${ }^{22}$ and for poorer children compared with richer children. ${ }^{25}$ Effects for some information-based, parentonly interventions were small. ${ }^{24}$ The most effective programmes were those with systematic training methods for the workers, a structured and evidence-based curriculum, and opportunities for parental practice with children with feedback. The total number of contacts with parents in these studies varied from two to more than 100 , but number of contacts was not clearly related to the size of the effect. However, a recent review of home visiting programmes reported that higher frequency of contact (at least fortnightly) was related to effectiveness. ${ }^{30}$

Of the four assessments of scaled-up programmes, in Uzbekistan small effects on parent activities but not child milestones were identified, ${ }^{27}$ and in The Gambia no effects were identified. ${ }^{27,28}$ Both assessments used community volunteers and incorporated early child development messages into pre-existing health and nutrition programmes. In Ecuador and central Asia moderate but consistent effects on child development were identified..$^{23,26}$ In Ecuador, the programme Educa tu Hijo (Educate your Child) was adapted from Cuba's model, which combines health care with a carefully structured parenting programme coordinated by the health sector and community committees. Children in the programme had higher cognitive scores than those not in the programme. ${ }^{23}$

In central Asia, the assessment of the implementation of the Care for Development module of Integrated Management of Childhood Illness noted that children's developmental scores were substantially higher in intervention districts than in similar control districts. There were also improvements in parents' activities with children and in health-worker recommendations. ${ }^{26}$ The Care for Development module, developed by WHO and UNICEF, trains health workers to provide specific behavioural recommendations to caregivers about play, communication, and responsive feeding. ${ }^{31}$ Two effectiveness studies (reported above) also assessed the Care for Development module and identified substantial effects on home stimulation ${ }^{20}$ and child development. ${ }^{18}$ In general, parenting programmes that were more effective had a well developed parenting curriculum, adequate training of workers, a balance of health, nutrition, and early child development components, and both community and governmental (local or national) support. ${ }^{23}$

In high-income countries, ${ }^{32}$ three meta-analyses of parenting and home visiting programmes ${ }^{32-34}$ identified similar factors contributing to programme effectiveness: systematic curricula, training for workers and parent educators, and active strategies to promote caregiver behaviour change, such as feedback, coaching, roleplay, and videotaped interactions. They also noted that the quality of the relationship between parent and worker was positively correlated with effectiveness. ${ }^{32,33,34}$ Long

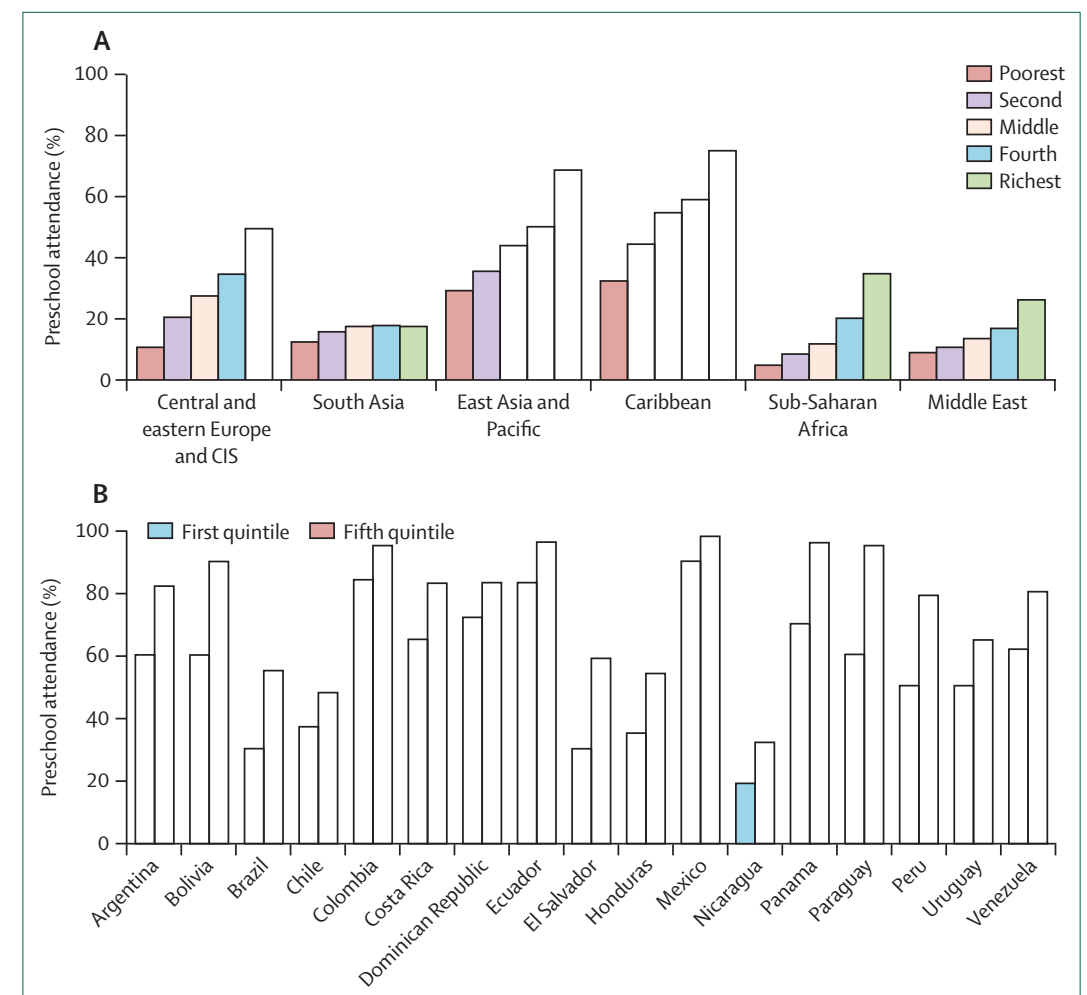

Figure 1: Proportion of young children attending preschool in 58 low-income and middle-income countries by income quintile within country summed across sample countries by region $(A)$ and by country in Latin America (B)

(A) Data are from the UNICEF's 2005 Multiple Indicator Cluster Survey 3 for children aged 3 and 4 years. Countries included in each region are Albania, Belarus, Bosnia and Herzegovina, Georgia, Kazakhstan, Kyrgyzstan, Macedonia, Serbia, Tajikistan, Ukraine, Uzbekistan (central and eastern Europe, CIS, and Baltic states); Bangladesh (south Asia); Laos, Mongolia, Thailand, Vanuatu, Vietnam (east Asia and Pacific); Belize, Guyana, Jamaica, Suriname, Trinidad and Tobago (Caribbean); Burkina Faso, Burundi, Cameroon, Central African Republic, Côte d'Ivoire, Djibouti, Gambia, Ghana, Guinea-Bissau, Malawi, Mauritania, Nigeria, Sierra Leone, Somalia, Togo (sub-Saharan Africa); Iraq, Lebanon, Syria, Yemen (Middle East). (B) Adapted from Vegas and Santibanez, ${ }^{6}$ with permission. The rates in Argentina, El Salvador, Honduras, Peru, and Venezuela are for children aged 3-6 years; in Bolivia, Colombia, Costa Rica, Mexico, Panama, and Paraguay for children aged 5-6 years; and in the Dominican Republic and Nicaragua are for children aged 4-6 years. In all other countries the rates are for children aged 0-6 years. Income quintiles are calculated within country and summed across regional areas. CIS=Commonwealth of Independent States.

duration did not necessarily result in better outcomes. A meta-analysis of US programmes, for example, identified that an intervention including only 16 effective, highFor the data from the Multiple Indicator Cluster Survey see http://www.childinfo.org quality sessions showed substantial effects on parentchild interactions. ${ }^{35}$

Although many low-income and middle-income countries have put child development messages on child health cards, growth charts, and so-called baby passports, there were few assessments of their effectiveness in low-income and middle-income countries. In one study in India, literate parents who kept a card with Care for Development messages for 2 months increased their recall, understanding, and reported appreciation of these messages. ${ }^{36}$

\section{Preschool, childcare centres, and daycare}

We also assessed effects of two preschool models: formal pre-primary or preschool programmes-generally linked 


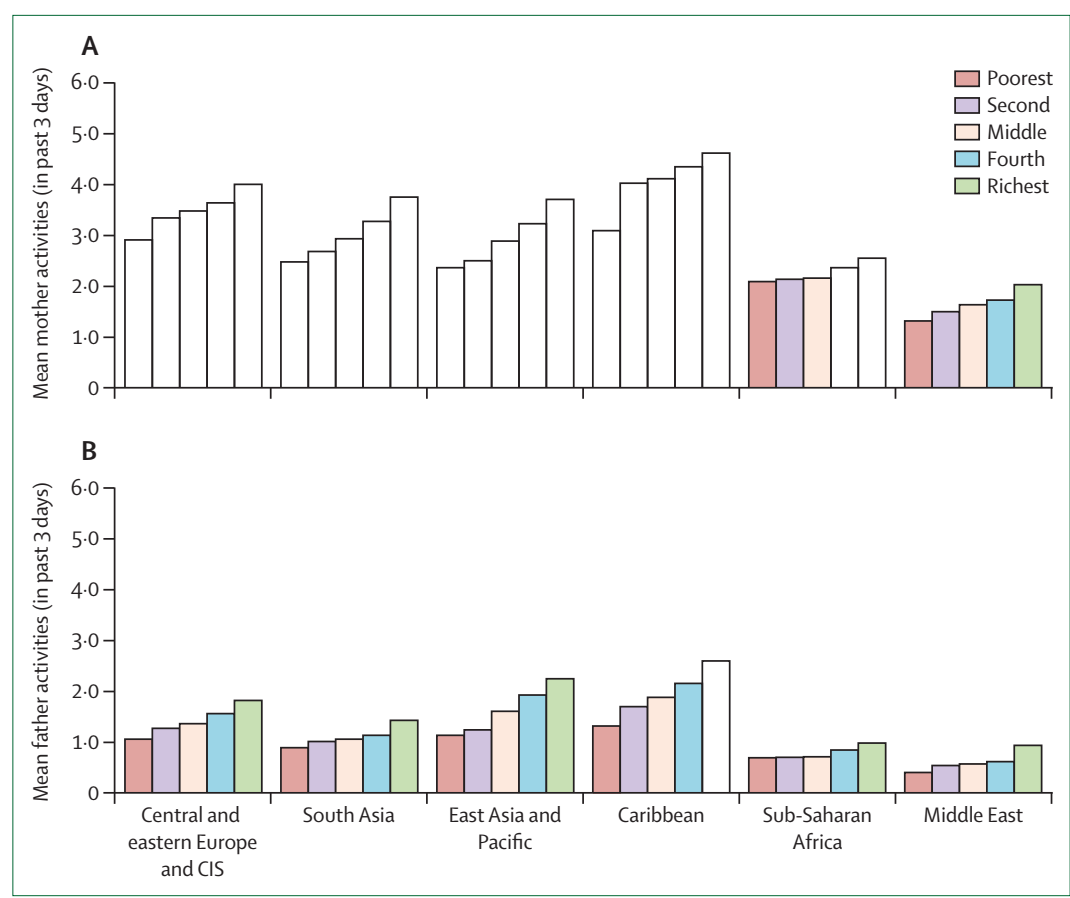

Figure 2: Mother's (A) and father's $(B)$ total activities in the past 3 days by sampled countries within region and within-country wealth quintile for 38 countries

Data are from the UNICEF's 2005 Multiple Indicator Cluster Survey 3. Countries included in each region are Albania, Belarus, Bosnia and Herzegovina, Georgia, Kazakhstan, Kyrgyzstan, Macedonia, Montenegro, Serbia, Tajikistan, Uzbekistan (central and eastern Europe, CIS, and Baltic states); Bangladesh (south Asia); Laos, Mongolia, Thailand, Vanuatu, Vietnam (east Asia and Pacific); Belize, Guyana, Jamaica, Suriname, Trinidad and Tobago (Caribbean); Burkina Faso, Burundi, Cameroon, Central African Republic, Côte d'Ivoire, Djibouti, Gambia, Ghana, Guinea-Bissau Mauritania, Nigeria, Sierra Leone, Somalia, Togo (sub-Saharan Africa); Iraq, Lebanon, Syria, Yemen (Middle East). $\mathrm{CIS}=$ Commonwealth of Independent States. comparing attendance at improved preschools with attendance at non-improved preschools. Unfortunately, no studies were identified that assessed the effect of daycare-the provision of full daycare for infants and young children of employed caregivers, which vary from offering only custodial care to educational care.

15 assessments (10 effectiveness studies and five programme assessments) met the relevant inclusion criteria (table 2 and webappendix pp 7-15). Nine studies, ${ }^{37-50}$ including five programme assessments, compared preschool attendees with non-attendees, controlling for initial differences. In eight, attendees had higher scores on one or more measures of child development, such as literacy, vocabulary, mathematics, quantitative reasoning, and teacher assessments of performance at the end of the year. In one programme assessment, attendees had lower cognitive scores than non-attendees. ${ }^{42}$ However, children who attended for more than 16 months scored higher on cognitive tests than age-matched children who had attended for 2 months or less. ${ }^{42}$ Only two of four studies that assessed the effects of preschools on social and behavioural development reported positive effects. ${ }^{39,52}$ Although the effects of non-formal preschools on child outcomes were typically weaker than the effects of formal preschools, some non-formal preschool programmes resulted in better early child development outcomes compared with non-participants. . $^{37,4,50}$

Similar to the parenting intervention findings, studies of children in preschools showed greater benefits for higher-risk ${ }^{39}$ or more disadvantaged ${ }^{41}$ children compared with lower-risk or less disadvantaged children. Often the longer-term benefits of preschool attendance decreased during primary school, $^{43}$ but some studies identified longer-term effects. Preschool attendance was associated with improved school performance through second and third grades in some reports, ${ }^{41,43,52}$ and effects were even larger in adolescence. ${ }^{52}$

Being enrolled in higher quality or improved preschool programmes compared with standard programmes was associated with better learning outcomes in all studies and programme assessments that compared them. ${ }^{43-51,53}$ Effective innovations included structured pre-reading programmes in Bangladesh ${ }^{48}$ and Costa Rica, ${ }^{51}$ formal rather than informal preschools in China and Cambodia, ${ }^{49,50}$ a teacher training programme in Jamaica, ${ }^{44}$ child-centred methods or interactive teacher-child methods of instruction in Bangladesh ${ }^{46}$ and east Africa, ${ }^{38,45}$ and interactive radio or audio instruction to guide classes for teachers in Zanzibar. ${ }^{47}$ Two studies identified that social and behavioural interventions led to improved behaviour, school success, and persistence. ${ }^{44,52}$ Interactive radio instruction has also been used in Bolivia, Honduras, Indonesia, and El Salvador at scale to improve the quality of the preschool experience, although it has not been assessed. ${ }^{54}$

The median effect sizes for preschool interventions,

when they could be calculated, were moderate and to schools or offered by private providers, with curricula, learning materials, paid and trained teaching staff, and a fixed classroom site-and non-formal or communitybased preschools, which tend not to have professionally trained teachers and might have locally adapted sites. We divided the preschool studies into those comparing preschool attendance with no attendance, and others 
similar for preschool attendance (median 0.24, range $-0 \cdot 14$ to 1.68$)$ and for quality improvements $(0 \cdot 28$, -0.23 to 0.69 ; table 2 ).

\section{Promising directions for programming}

Since poverty is a root cause of poor child development, some approaches to improving early child development are aimed at making those improvements through poverty alleviation. Cash transfer programmes are a popular approach to long-term poverty alleviation; ${ }^{55,56}$ the expectation of conditional cash transfer programmes is that families use cash transfers both to help parents provide for their children's needs and as an incentive for parents to invest in their children's health and education. . $^{57}$ -

Many conditional cash transfer programmes distribute benefits conditional on mandatory attendance at preventive health-care services and health and nutrition education sessions designed to promote positive behavioural changes, and some programmes also require school attendance for children of school age. Whether conditionality makes a difference in the outcomes of cash transfer programmes is a crucial research question. We are aware of only three evaluations of cash transfer programmes in Latin America that have included assessments of cognitive or language function in preschool children (Mexico, ${ }^{60,61}$ Nicaragua, ${ }^{62}$ and Ecuador ${ }^{63,64}$ ) and programme effects on cognition and language development are generally positive, but small. Some cash transfer programmes (eg, Mexico's Oportunidades) are at present experimenting with the inclusion of programme requirements that involve the promotion of child development (eg, parents must participate in weekly classes on parenting).

As television and radio ownership increases in lowincome and middle-income countries, educational programming (content that is educational, non-violent, and designed for young children) might be a viable option for improving early child development (webappendix pp 16-17). Sesame Street, for example, is available in more than 120 countries. ${ }^{65}$ Research from the USA shows benefits of educational programming on the cognitive development and social understanding ${ }^{65}$ of children older than 2 years, ${ }^{66}$ but non-educational television has been linked with outcomes such as child obesity and violent behaviour. ${ }^{65}$

Two effectiveness studies in low-income and middleincome countries have shown positive effects of educational television (a Bangladeshi Sesame Street [Sisimpur] and a Turkish experimental children's programme) on child mathematics and literacy scores. ${ }^{67,68}$ Bangladeshi families reported doing more to support their children's learning after viewing the programme, ${ }^{69}$ and in a longitudinal study poorer children benefited more..$^{70}$ Children's television can also increase young children's acceptance of negatively perceived groups

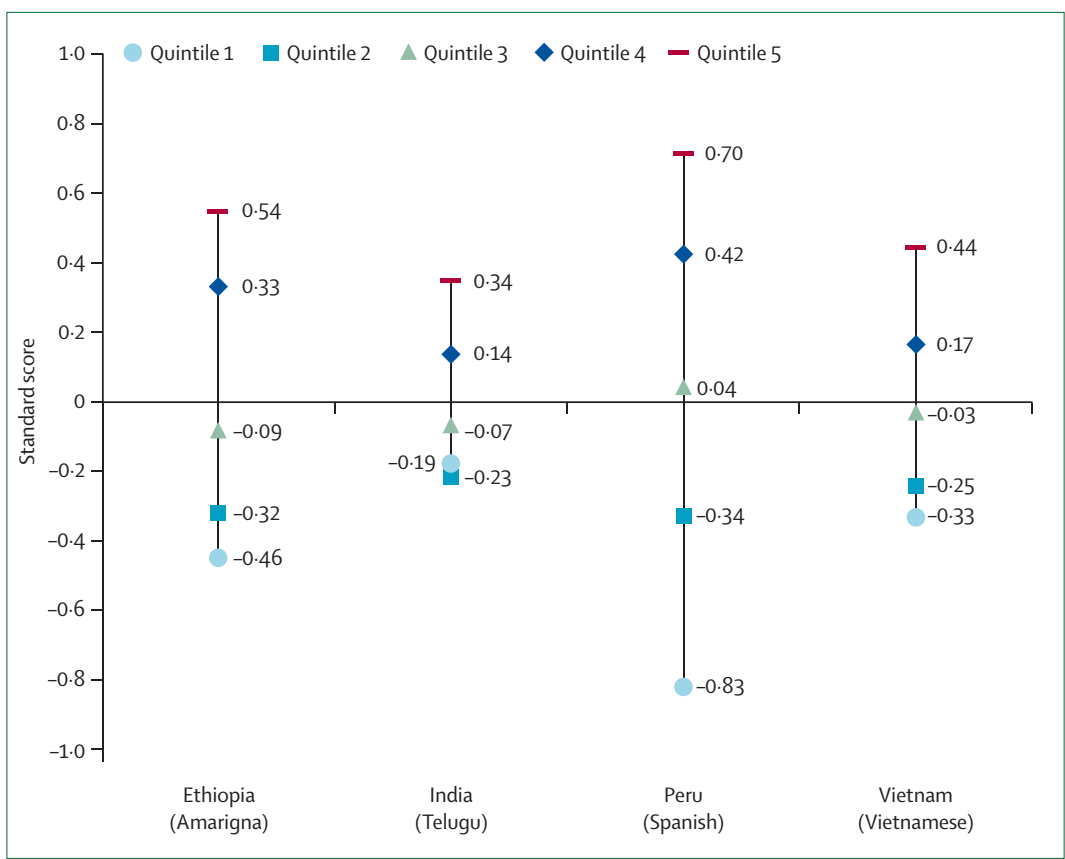

Figure 3: Peabody Picture Vocabulary Test ${ }^{7}$ standard scores by country and quintile of expenditure Data for children (aged 5-6 years) speaking the majority language of the region or country (in parentheses).

Panel 2: Conclusions from the analysis of intervention effects

- Parenting education and support can improve children's cognitive and psychosocial development

- Effects are larger in more disadvantaged populations

- Effects are larger when there are systematic curricula and training opportunities for childcare workers and parents

- Effects are larger when there are active strategies to show and promote caregiving behaviours-eg, practice, role play, or coaching to improve parent-child interactions

- Centre-based early learning programmes usually improve children's cognitive functioning, readiness for school, and school performance

- Effects are larger for children from disadvantaged circumstances

- Effects are larger as a result of higher quality programmes, whether formal or informal

- Promising directions for interventions include expanding educational media for children, and linking conditional cash transfers and nutrition with early child development interventions

- Although there are some reports attesting to the effectiveness of interventions for high-risk children in low-income and middle-income countries, evidence is not yet sufficient to establish best approaches

(eg, Israelis and Palestinians).$^{71}$ In poor families in highincome countries, providing books for young children through primary health services has been shown to increase how often parents read to their children and to improve child language. ${ }^{11}$

\section{Children at risk of not reaching their potential}

Substantial numbers of children experience risks to their development, in addition to poverty and malnutrition. These risks include physical and developmental 


\begin{tabular}{|c|c|c|c|c|c|}
\hline & Country & Intervention and number of visits & Outcome & Results & Effect size \\
\hline \multicolumn{6}{|c|}{ Focused primarily on both parent and child } \\
\hline Aboud and Akhter $2011^{14}$ & Bangladesh & $\begin{array}{l}\text { Six parent group sessions of } \\
\text { coaching on responsive feeding and } \\
\text { stimulation }\end{array}$ & $\begin{array}{l}\text { HOME score }(A) \text {, responsive } \\
\text { talk }(B), \text { Bayley III language } \\
\text { score }(C)\end{array}$ & $\begin{array}{l}\text { Intervention groups had significantly } \\
\text { higher scores than controls at follow-up } \\
(A, B \text {, and } C)\end{array}$ & $\begin{array}{l}\text { Reported as d } 0.38(\mathrm{~A}) \\
0.40(\mathrm{~B}) \text {, and } 0.35(\mathrm{C})\end{array}$ \\
\hline Cooper et al $2009^{16}$ & South Africa & $\begin{array}{l}\text { Home Visit Parenting intervention } \\
\text { (16 visits) }\end{array}$ & $\begin{array}{l}\text { Quality of mother-infant } \\
\text { interaction at } 6 \text { and } \\
12 \text { months }(A) \text { and infant } \\
\text { attachment }(B)\end{array}$ & $\begin{array}{l}\text { Treatment mothers were significantly more } \\
\text { sensitive and less intrusive at } 6 \text { and } \\
12 \text { months }(A) \text { and significantly higher rates } \\
\text { of infant attachment (B) }\end{array}$ & $\begin{array}{l}\text { Reported as } \mathrm{d} 0.24 \\
\text { to } 0.86(\mathrm{~A}) \text {, and } \\
\text { unavailable }(\mathrm{B})\end{array}$ \\
\hline Jin et al $2007^{18}$ & China & $\begin{array}{l}\text { Care for Development Intervention } \\
\text { with primary health care (two } \\
\text { visits) }\end{array}$ & $\begin{array}{l}\text { Gesell Developmental } \\
\text { Schedules }\end{array}$ & $\begin{array}{l}\text { No substantial differences between } \\
\text { treatment and control in motor scale, but } \\
\text { treatment children had significantly } \\
\text { higher scores in language, social, and } \\
\text { adaptive scales }\end{array}$ & $\begin{array}{l}\text { Calculated from pretest } \\
\text { and post-test changes as } \\
\text { d } 0.28-0.66\end{array}$ \\
\hline Kagitcibasi $2009^{21}$ & Turkey & $\begin{array}{l}\text { Three (educational centre, } \\
\text { custodial centre, or control) by two } \\
\text { (mother training or control) design } \\
\text { for } 4-6 \text { year children (mother } \\
\text { training intervention: } 60 \text { weeks of } \\
\text { home visit and monthly groups) }\end{array}$ & $\begin{array}{l}19 \text { year follow-up in early } \\
\text { adulthood compared } \\
\text { mother training or not } \\
\text { (1), early childcare or not } \\
\text { (2), and any enrichment } \\
\text { or not (3) for cognitive } \\
\text { composite (A) and social } \\
\text { composite and subscales } \\
\text { (B) }\end{array}$ & $\begin{array}{l}\text { No effects on cognitive or social } \\
\text { composite (1); no effect for cognitive } \\
\text { outcome, but significant difference on } \\
\text { social composite at each age ( } 2 \text { ); higher } \\
\text { proportion of enriched went to college, } \\
\text { had higher educational attainment } \\
\text { (significant for males), had higher status } \\
\text { occupations, and were more likely to own } \\
\text { a computer ( } 3 \text { ) }\end{array}$ & $\begin{array}{l}\text { Reported d } 0 \cdot 20(1 \mathrm{~A}) \text {, } \\
\text { unavailable }(1 \mathrm{~B}), \\
\text { unavailable }(2 \mathrm{~A}), \\
\text { unavailable }(2 \mathrm{~B}), \\
\text { unavailable }(3 \mathrm{~A}), \\
\text { calculated } 0 \cdot 35(3 \mathrm{~B})\end{array}$ \\
\hline Klein and Rye $2004^{17}$ & Ethiopia & $\begin{array}{l}\text { Meditational Interaction for } \\
\text { Sensitive Caregiving video tapes } \\
\text { with feedback and awareness } \\
\text { raising (five home visits and five } \\
\text { groups) }\end{array}$ & $\begin{array}{l}\text { Development checklist (A), } \\
\text { MacArthur Communicative } \\
\text { Development Inventory } \\
\text { (B), Rutter's Scale of Social } \\
\text { and Emotional } \\
\text { development (C), school } \\
\text { achievement } 6 \text { years } \\
\text { later (D) }\end{array}$ & $\begin{array}{l}\text { No significant differences }(A) \text {, treatment } \\
\text { had higher vocabulary scores (B), no } \\
\text { significant differences }(C) \text {, and significant } \\
\text { differences in school attendance and } \\
\text { achievement (D) }\end{array}$ & Unavailable \\
\hline Leung et al $2003^{19}$ & China & $\begin{array}{l}\text { Group sessions with Triple } P \\
\text { methods for parents of children } \\
\text { with behaviour difficulties (four } \\
\text { groups and follow-up) }\end{array}$ & $\begin{array}{l}\text { Parent daily report of } \\
\text { problems (A), Eyberg Child } \\
\text { Behaviour Inventory } \\
\text { subscales (B), and } \\
\text { Strengths and Difficulty } \\
\text { Scale subscales (C) }\end{array}$ & $\begin{array}{l}\text { Treatment children had significantly better } \\
\text { scores on all outcomes (A, B, and C) }\end{array}$ & $\begin{array}{l}\text { Calculated, no covariates } \\
\text { d } 0.56(\mathrm{~A}) \text {, reported } \\
0.9 \text { to } 0.97(\mathrm{~B}) \text {, and } \\
\text { calculated, no covariates } \\
0.48 \text { to } 0.77(\mathrm{C})\end{array}$ \\
\hline $\begin{array}{l}\text { Janssens and Rosemberg } \\
2011^{22}\end{array}$ & St Lucia & $\begin{array}{l}\text { Roving Caregivers Programme-- } \\
\text { home visits two times per week } \\
\text { (about } 104 \text { visits) }\end{array}$ & $\begin{array}{l}\text { Cognitive scales (Mullen } \\
\text { Scales of Early } \\
\text { Development) }\end{array}$ & $\begin{array}{l}\text { Significant effect on youngest birth cohort } \\
\text { in treatment group compared to control } \\
\text { group (aged 6-18 months at programme } \\
\text { start; A) and no significant affect for } \\
\text { oldest birth (aged 18-30 months at } \\
\text { programme start; B) }\end{array}$ & $\mathrm{d} 0.45(\mathrm{~A})$ and $0.04(\mathrm{~B})$ \\
\hline $\begin{array}{l}\text { Tinajero } 2010 \text { (Asociación } \\
\text { Velnec-RH } 2004)^{23}\end{array}$ & Ecuador (scaled up) & $\begin{array}{l}\text { Comprehensive parenting, health, } \\
\text { nutrition, and community }\end{array}$ & $\begin{array}{l}\text { Abbreviated development } \\
\text { scale }\end{array}$ & $\begin{array}{l}\text { Treatment children had significantly higher } \\
\text { scores on all subscales than control children }\end{array}$ & Unavailable \\
\hline \multicolumn{6}{|c|}{ Focused primarily on parent and family } \\
\hline $\begin{array}{l}\text { Al-Hassan and Lansford } \\
2010^{24}\end{array}$ & Jordan & $\begin{array}{l}\text { Better Parenting Program: parent } \\
\text { groups ( } 16 \text { hours in parent group, } \\
\text { over } 1-2 \text { months) }\end{array}$ & $\begin{array}{l}\text { Parent report of cognitive } \\
\text { and social activities with } \\
\text { children, discipline, } \\
\text { knowledge ( } 43 \text { questions) }\end{array}$ & $\begin{array}{l}\text { Intervention group improved significantly } \\
\text { and control did not on two of } 12 \text { activities } \\
\text { (play and read), two of } 15 \text { discipline } \\
\text { questions, four of } 16 \text { knowledge questions }\end{array}$ & Unavailable \\
\hline Bentley et al $2010^{15}$ & India & $\begin{array}{l}\text { Home visits to improve } \\
\text { complementary food (1); } \\
\text { complementary food, responsive } \\
\text { feeding, and play (2); (ICDS; 30-40 } \\
\text { home visits) }\end{array}$ & $\begin{array}{l}\text { Bayley Scales (Mental and } \\
\text { Motor scales; A) and } \\
\text { HOME score (B) }\end{array}$ & $\begin{array}{l}\text { Scores were significantly greater in both } \\
\text { treatment groups for mental development } \\
\text { scale but not motor (A) and HOME total } \\
\text { scores were significantly larger for } \\
\text { treatment group at } 15 \text { months but not at } \\
\text { earlier months (B) }\end{array}$ & $\begin{array}{l}\text { Calculated effect size, no } \\
\text { covariates d } 0.03 \text { to } 0.11 \\
(1 \mathrm{~A}), 0.06 \text { to } 32(1 \mathrm{~B}) \text {, } \\
0.12 \text { to } 30(2 \mathrm{~A}) \text {, and } 0.11 \\
\text { to } 0.32(2 \mathrm{~B})\end{array}$ \\
\hline Ertem et al $2006^{20}$ & Turkey & $\begin{array}{l}\text { Care for Development Intervention } \\
\text { with primary health care (two } \\
\text { visits) }\end{array}$ & HOME scores & $\begin{array}{l}\text { No significant differences in mean HOME } \\
\text { score between treatment and control but } \\
\text { treatment families were significantly more } \\
\text { likely to have optimum HOME scores }\end{array}$ & Unavailable \\
\hline Palti et al $1982^{25}$ & $\begin{array}{l}\text { Israel (not low or } \\
\text { middle income but } \\
\text { disadvantaged in } \\
\text { 1982) }\end{array}$ & $\begin{array}{l}\text { Parenting intervention through } \\
\text { primary health care } \\
\text { (1 year of visits) }\end{array}$ & Developmental Quotient & $\begin{array}{l}\text { No significant difference in Developmental } \\
\text { Quotient scores between treatment and } \\
\text { control group; however, there were } \\
\text { significant differences for treatment group } \\
\text { that received "good stimulation" }\end{array}$ & $\begin{array}{l}\text { Calculated, no covariates } \\
\text { d } 0.11\end{array}$ \\
\hline
\end{tabular}




\begin{tabular}{|c|c|c|c|c|c|}
\hline & Country & Intervention and number of visits & Outcome & Results & Effect size \\
\hline \multicolumn{6}{|c|}{ (Continued from previous page) } \\
\hline Engle et al $2010^{26}$ & $\begin{array}{l}\text { Kyrgyzstan, Tajikistan } \\
\text { (scaled up) }\end{array}$ & $\begin{array}{l}\text { Care for Development Intervention } \\
\text { in Tajikistan (1) and Kyrgyzstan } \\
\text { with primary health care ( } 2 \text {; } \\
\text { number of sessions not known, } \\
\text { recommended to be monthly for } \\
\text { first year) }\end{array}$ & $\begin{array}{l}\text { Early Learning and } \\
\text { Development Standards } \\
\text { (A) and Ages and } \\
\text { Stages Questionnaire } \\
\text { subscales (B) }\end{array}$ & $\begin{array}{l}\text { Children's score was significantly higher in } \\
\text { intervention areas than control areas }(1 \mathrm{~A}) \text {; } \\
\text { children's score was significantly higher in } \\
\text { intervention areas for communication, } \\
\text { gross motor, and personal social but not } \\
\text { fine motor or problem solving }(1 \mathrm{~B}) \text {; and } \\
\text { children's score was significantly higher in } \\
\text { intervention areas for communication and } \\
\text { personal social but not fine motor, gross } \\
\text { motor, or problem solving (2B) }\end{array}$ & $\begin{array}{l}\text { Calculated effect size, no } \\
\text { covariates d } 0.34(1 \mathrm{~A}) \text {, } \\
\text { unavailable }(1 \mathrm{~B}) \text {, and } \\
\text { range } 0.06 \text { to } 0.29(2 \mathrm{~B})\end{array}$ \\
\hline Nodira et al $2009^{27}$ & $\begin{array}{l}\text { Uzbekistan (scaled } \\
\text { up) }\end{array}$ & $\begin{array}{l}\text { Family empowerment } \\
\text { programme-large-scale } \\
\text { community-based health and } \\
\text { nutrition programme (number of } \\
\text { contacts not specified) }\end{array}$ & $\begin{array}{l}\text { Child milestones of } \\
\text { development, parent } \\
\text { activities with children, } \\
\text { parent knowledge }\end{array}$ & $\begin{array}{l}\chi^{2} \text { analysis of child milestones by parent } \\
\text { report, and parent behaviours by parent } \\
\text { report between intervention and } \\
\text { non-intervention areas showed some } \\
\text { significant differences in parent skills and } \\
\text { parent knowledge }\end{array}$ & Unavailable \\
\hline Sidibeh $2009^{28}$ & $\begin{array}{l}\text { The Gambia (scaled } \\
\text { up) }\end{array}$ & $\begin{array}{l}\text { Parenting intervention through } \\
\text { community actions as part of } \\
\text { breastfeeding programme (number } \\
\text { of contacts not specified) }\end{array}$ & $\begin{array}{l}\text { Parent knowledge, beliefs, } \\
\text { and reported activities } \\
\text { with children }\end{array}$ & $\begin{array}{l}\text { No difference in parent beliefs and practices } \\
\text { in child-rearing }\end{array}$ & Unavailable \\
\hline \multicolumn{6}{|c|}{$\begin{array}{l}\text { Design details in webappendix pp 1-6. If effect sizes were not reported we calculated a Cohen's } d \text { (d) effect sizes from either post-test means, differences from pretest to post-test means, or from ordinary least } \\
\text { squares regression results. We focused on main effects and not subgroups, unless results were only presented by subgroups. If results were only presented by subgroups, then we reported the range of the effect } \\
\text { size. We also reported the range for tests that had subscales. If studies did not report Cohen's d effect sizes, and we did not have the information to calculate them, then we reported unavailable. HOME=Home } \\
\text { Observation for Measurement of the Environment. }{ }^{29}\end{array}$} \\
\hline
\end{tabular}

disabilities, severe acute malnutrition, being small for gestational age and low birthweight (LBW), and being infected with HIV/AIDS (webappendix pp 18-20).

\section{Children with developmental disabilities}

Few studies have assessed intervention models for children with disabilities in low-income and middle-income countries. One randomised clinical trial in Bangladesh reported that rural children with disabilities whose caregivers received a parenting training package progressed more on adaptive skills and that the mothers improved in their support for their children, compared with a minimal intervention..$^{72}$ Community-based rehabilitation, a strategy advocated by WHO, is widely used but not well assesseda review of 128 published studies identified few robust assessments. $^{73}$ Studies recommend broader community awareness and more evidence, more screening and referral services, and caregiver support. ${ }^{72,74}$

\section{Children with severe acute malnutrition}

WHO recommends incorporating stimulation into management strategies for children with malnutrition, in addition to food supplementation and health care, ${ }^{75}$ but we identified few studies testing the effects of such integrated programmes. One study in Bangladesh ${ }^{76}$ and one in Uganda ${ }^{\pi}$ showed positive effects of stimulation on early child development for severely malnourished children.

\section{Children small for gestational age or LBW}

Early interventions for LBW infants in high-income countries improve cognitive and social-emotional development with effects lasting into childhood and adult years. ${ }^{78-81}$ In Jamaica, weekly home visits for LBW term infants resulted in higher development quotients at 6 years. $^{82}$ In India, mothers of at-risk infants (75\% LBW, premature, or both) were randomly assigned to receive training to provide stimulation at home over 12 months. At both 12 months and 2 years, intervention children's cognitive development was greater. ${ }^{83}$ Ongoing work in India, Pakistan, and Zambia will provide more data on early stimulation for at-risk infants in community-based settings. ${ }^{84}$

\section{Children affected and infected by HIV/AIDS}

Young children in communities affected by the AIDS pandemic are exposed to many threats. Even though fewer young children are becoming infected because of the increase in programmes for the prevention of mother-to-child transmission, the overall number of vulnerable and infected children, particularly in subSaharan Africa, is high..$^{85}$ Interventions to improve early child development for these children include supporting caregivers' capacity through home visits, cash transfer systems (eg, so-called child grants in South Africa), preschool programmes, and legal protection strategies. ${ }^{70,86}$ In a randomised controlled trial, a home stimulation programme provided to caregivers of infants infected with HIV at clinic visits every 3 months resulted in substantially higher cognitive scores at 12 months. ${ }^{87}$

Many qualitative or pre-test and post-test design studies have shown benefits of these programmes on the child-rearing behaviours of caregivers, and on 


\begin{tabular}{|c|c|c|c|c|c|}
\hline & Country & Intervention and child age & Outcome & Results & Effect size \\
\hline \multicolumn{6}{|c|}{ Preschool attendance $v s$ none } \\
\hline Aboud et al $2008^{37}$ & Bangladesh & $\begin{array}{l}\text { Preschool attendance vs } \\
\text { none (children aged } 5 \text { years) }\end{array}$ & $\begin{array}{l}\text { First grade reading }(A) \text { and } \\
\text { first grade mathematics }(B)\end{array}$ & $\begin{array}{l}\text { Preschool graduates scored higher than non-attendees } \\
\text { in reading and writing }(A) \text { and preschool graduates } \\
\text { scored higher than non-attendees in oral but not } \\
\text { written mathematics (B) }\end{array}$ & $\begin{array}{l}\text { Effect sizes unavailable; reported as } \\
\text { "small" by the authors }\end{array}$ \\
\hline Mwaura et al $2008^{38}$ & $\begin{array}{l}\text { Kenya, } \\
\text { Uganda, and } \\
\text { Zanzibar }\end{array}$ & $\begin{array}{l}\text { Madrasa preschool (1), } \\
\text { non-Madrasa preschool (2), } \\
\text { and none (3); children aged } \\
\text { 3-5 years }\end{array}$ & $\begin{array}{l}\text { British Ability Scales (A; } \\
\text { subscales) and African Child } \\
\text { Intelligence Test } \\
\text { (B; subscales) }\end{array}$ & $\begin{array}{l}\text { Significant improvements in scores for treatment } \\
\text { children vs children with no preschool on both outcomes } \\
(1 \mathrm{~A}, 1 \mathrm{~B}) \text { and significant improvements in scores for } \\
\text { treatment children vs non-Madrasa on all African Child } \\
\text { Intelligence Test outcomes and verbal comprehension } \\
\text { and number concept subscales (British Ability Scales; } 2 \mathrm{~A} \text {, } \\
\text { 2B) }\end{array}$ & $\begin{array}{l}\text { Calculated from regressions with } \\
\text { covariates d } 0.50 \text { to } 0.79(1 \mathrm{~A}) \\
0.86 \text { to } 0.95(1 \mathrm{~B}), 0.08 \text { to } 0.46 \\
(2 \mathrm{~A}) \text {, and } 0.27 \text { to } 0.59 \text { (2B) }\end{array}$ \\
\hline Raine et al $2003^{39}$ & Mauritius & $\begin{array}{l}\text { Enriched Preschool } \\
\text { programme vs none for } \\
\text { children aged } 3-5 \text { years }\end{array}$ & $\begin{array}{l}\text { Behaviour problems }(A) \text { and } \\
\text { schizotypal personality }(B)\end{array}$ & $\begin{array}{l}\text { Treatment group had significantly better scores than } \\
\text { control (A) and treatment group had significantly better } \\
\text { scores than control at age } 17 \text { years but not } 23 \text { (B) }\end{array}$ & $\begin{array}{l}\text { Reported range } \mathrm{d} 0.31 \text { to } 0.44(\mathrm{~A}) \\
\text { and } 0.34(17 \text { years; } \mathrm{B})\end{array}$ \\
\hline $\begin{array}{l}\text { Urzua and } \\
\text { Veramendi } 2010^{40}\end{array}$ & Chile & $\begin{array}{l}\text { Preschool vs none (children } \\
\text { aged } 2-5 \text { years) }\end{array}$ & $\begin{array}{l}\text { TESPI (Spanish IQ test } \\
\text { 2-5 years; A), Peabody } \\
\text { Picture Vocabulary Test (B), } \\
\text { child behaviour checklist } \\
\text { (C), and child behaviour } \\
\text { questionnaire (D) }\end{array}$ & $\begin{array}{l}\text { Children who attended had significantly higher scores } \\
\text { than those who did not attend (A); no significant } \\
\text { difference between children attending daycare and } \\
\text { those not attending }(B, C \text {, and } D)\end{array}$ & Unavailable ( A, B, C, and D) \\
\hline $\begin{array}{l}\text { Berlinkski et al } \\
2008^{41}\end{array}$ & $\begin{array}{l}\text { Uruguay } \\
\text { (scaled up) }\end{array}$ & $\begin{array}{l}\text { Pre-primary education vs } \\
\text { none (children aged } \\
3-5 \text { years) }\end{array}$ & $\begin{array}{l}\text { Years of education (A) and } \\
\text { school attendance (B) }\end{array}$ & $\begin{array}{l}\text { Treatment children older than } 8 \text { years have significantly } \\
\text { more years of education (A) and treatment children } \\
\text { older than } 11 \text { years are significantly more likely to be in } \\
\text { school (B) }\end{array}$ & $\begin{array}{l}\text { Calculated from regressions with } \\
\text { covariates d } 0.02 \text { to } 0.19(\mathrm{~A}) \text {, and } \\
0.01 \text { to } 0.12 \text { (B) }\end{array}$ \\
\hline Bernal et al $2009^{42}$ & $\begin{array}{l}\text { Colombia } \\
\text { (scaled up) }\end{array}$ & $\begin{array}{l}\text { Community childcare } \\
\text { centres vs none (children } \\
\text { aged } 2-5 \text { years) }\end{array}$ & $\begin{array}{l}\text { Early Development } \\
\text { Inventory (EDI) psychosocial } \\
\text { (A), EDI cognitive (B), TVIP } \\
\text { (Spanish vocabulary test; C), } \\
\text { Woodcock Munoz scales } \\
\text { (D), and fifth grade } \\
\text { achievement test (E) }\end{array}$ & $\begin{array}{l}\text { No significant difference between treatment and control } \\
\text { (A); treatment children had significantly lower scores; } \\
\text { however, treatment children with more than } 15 \text { months } \\
\text { of exposure had significantly higher scores (B, C, and D); } \\
\text { and treated children had significantly higher test scores (E) }\end{array}$ & $\begin{array}{l}\text { Calculated, no covariates d } 0.02 \\
(A),-0.1(B),-0.14(C) \text {, and }-0.05 \\
\text { to } 0.08(D) ; \text { and calculated from } \\
\text { instrument variable regression } \\
\text { with covariates d } 0.11 \text { (E) }\end{array}$ \\
\hline \multicolumn{6}{|c|}{ Improvements in preschool compared with non-improved preschools } \\
\hline $\begin{array}{l}\text { Aboud and Hossain } \\
2011^{43}\end{array}$ & $\begin{array}{l}\text { Bangladesh } \\
\text { (scaled up) }\end{array}$ & $\begin{array}{l}\text { Preschool with three levels } \\
\text { of quality vs no preschool } \\
\text { (all children aged } 5 \text { years) }\end{array}$ & $\begin{array}{l}\text { First grade mathematics } \\
\text { (A), first grade language } \\
\text { (B), second grade } \\
\text { mathematics (C), and } \\
\text { second grade language (D) }\end{array}$ & $\begin{array}{l}\text { Graduates of highest quality preschool scored } \\
\text { significantly higher than graduates of lower } 2 \text { groups, } \\
\text { preschool children (highest quality programme) perform } \\
\text { significantly better than non-preschool children on all } \\
\text { first grade outcomes (A, B), and preschool children } \\
\text { (highest quality programme) perform significantly } \\
\text { better than non-preschool children on all but reading } \\
\text { second grade outcomes (C, D) }\end{array}$ & $\begin{array}{l}\text { Reported differences between } \\
\text { preschool graduates from highest } \\
\text { quality programme and } \\
\text { comparisons controlling for } \\
\text { confounding variables } 0.36 \text { to } \\
0.59 \text { (A), } 0.53 \text { to } 0.67 \text { (B), } 0.19 \text { to } \\
0.36 \text { (C), and } 0.58 \text { (D) }\end{array}$ \\
\hline $\begin{array}{l}\text { Baker-Henningham } \\
\text { et al } 2009^{44}\end{array}$ & Jamaica & $\begin{array}{l}\text { "Incredible years" teacher } \\
\text { training programme vs } \\
\text { standard preschool (children } \\
\text { aged 3-5 years) }\end{array}$ & Child behaviour & $\begin{array}{l}\text { Significant improvements in child behaviour for children } \\
\text { in treatment group }\end{array}$ & Unavailable \\
\hline $\begin{array}{l}\text { Malmberg et al } \\
2011^{45}\end{array}$ & $\begin{array}{l}\text { Kenya, } \\
\text { Uganda, and } \\
\text { Zanzibar }\end{array}$ & $\begin{array}{l}\text { Madrasa Resource Centre vs } \\
\text { other preschools (children } \\
\text { aged 3-5 years) }\end{array}$ & Cognitive score & Treatment group had significantly higher cognitive scores & $\begin{array}{l}\text { Calculated from regressions with } \\
\text { fixed effects } \mathrm{d} 0 \cdot 4\end{array}$ \\
\hline Moore et al $2008^{46}$ & Bangladesh & $\begin{array}{l}\text { Improved preschool vs } \\
\text { standard (children aged } \\
4-5 \text { years) }\end{array}$ & $\begin{array}{l}\text { Wechsler Preschool and } \\
\text { Primary Scale of } \\
\text { Intelligence subsets (A) and } \\
\text { play observation scale (B) }\end{array}$ & $\begin{array}{l}\text { Significant increases in scores for treatment children (A) } \\
\text { and no significant increases in scores (B) }\end{array}$ & $\begin{array}{l}\text { Reported d } 0.04 \text { to } 0.08(A) \text { and } \\
\text { unavailable }(B)\end{array}$ \\
\hline Morris et al $2009^{47}$ & Zanzibar & $\begin{array}{l}\text { Radio instruction in } \\
\text { preschools vs standard } \\
\text { preschools (children aged } \\
3-5 \text { years) }\end{array}$ & $\begin{array}{l}\text { Mathematics test }(A) \text {, } \\
\text { English test }(B), \text { and } \\
\text { Kiswahili test }(C)\end{array}$ & $\begin{array}{l}\text { Treatment children had significantly higher scores on all } \\
\text { outcomes (A, B, and C) }\end{array}$ & $\begin{array}{l}\text { Reported d } 0.47(A), 0.29(B) \text {, } \\
\text { and } 0.69(C)\end{array}$ \\
\hline Opel et al $2009^{48}$ & Bangladesh & $\begin{array}{l}\text { Dialogic reading vs standard } \\
\text { preschool (children aged } \\
5 \text { years) }\end{array}$ & Vocabulary test & $\begin{array}{l}\text { Significant increases in vocabulary scores for } \\
\text { treatment children }\end{array}$ & Reported d 0.2 \\
\hline \multirow[t]{2}{*}{ Rao et al $2011^{49}$} & $\begin{array}{l}\text { Cambodia } \\
\text { (scaled up) }\end{array}$ & $\begin{array}{l}\text { Formal preschool }(1) \text {, } \\
\text { community preschool ( } 2) \text {, } \\
\text { home based ( } 3) \text {, and no } \\
\text { preschool ( } 3-5 \text { years; } 4)\end{array}$ & Locally developed test & $\begin{array}{l}\text { All three groups had significantly higher scores on } \\
\text { post-test controlling for pretest and confounding } \\
\text { factors than controls; home based did not differ from } \\
\text { the other two, but children in formal preschools scored } \\
\text { higher than those in community preschools }\end{array}$ & $\begin{array}{l}\text { Calculated d } 1.68 \text { ( } 1 \text { vs } 4), 1.01 \\
(2 \text { vs } 4), 1.00 \text { ( } 3 \text { vs } 4), 0.68 \text { ( } 1 \text { vs } 3), \\
0.02 \text { ( } 2 \text { vs } 3) \text {, and } 0.66 \text { ( } 1 \text { vs } 2)\end{array}$ \\
\hline & & & & & (Continues on next page) \\
\hline
\end{tabular}




\begin{tabular}{|c|c|c|c|c|c|}
\hline & Country & Intervention and child age & Outcome & Results & Effect size \\
\hline \multicolumn{6}{|c|}{ (Continued from previous page) } \\
\hline Rao et al $2011^{50}$ & $\begin{array}{l}\text { China } \\
\text { (scaled up) }\end{array}$ & $\begin{array}{l}\text { Kindergarten-child centred } \\
\text { (1), separate preschool (2), } \\
\text { children sit in regular first } \\
\text { grade classroom (mixed; } 3 \text {, } \\
\text { and no preschool (children } \\
\text { aged 5years; 4) }\end{array}$ & $\begin{array}{l}\text { First grade school } \\
\text { preparedness (A), literacy } \\
\text { (B), and mathematics (C) }\end{array}$ & $\begin{array}{l}\text { Treatment children had significantly higher scores on all } \\
\text { outcomes than no preschool (1), treatment children had } \\
\text { higher scores on all outcomes than no preschool (2), and } \\
\text { treatment children were not significantly different than } \\
\text { control children for any outcomes (3) }\end{array}$ & $\begin{array}{l}\text { Calculated, no covariates d } 1.63 \\
(1 \mathrm{~A}), 0.86(1 \mathrm{~B}), 1.07(1 \mathrm{C}), 0.28 \\
(2 \mathrm{~A}), 0.23(2 \mathrm{~B}), 0.57(2 \mathrm{C}),-0.43 \\
(3 \mathrm{~A}),-0.23(3 \mathrm{~B}), \text { and } 0.15(3 \mathrm{C})\end{array}$ \\
\hline Rolla et al $2006^{51}$ & Costa Rica & $\begin{array}{l}\text { Quality interventions: } \\
\text { classroom activities (1), } \\
\text { work with families (2), } \\
\text { tutoring (3), combination } \\
\text { (4), and controls (children } \\
\text { aged 4-5 years; 5) }\end{array}$ & $\begin{array}{l}\text { Print composite }(\mathrm{A}) \text { and } \\
\text { language composite }(\mathrm{B})\end{array}$ & $\begin{array}{l}\text { No significant differences between treatment and } \\
\text { control children (1), no significant differences between } \\
\text { treatment and control children (2), significant } \\
\text { differences between treatment and control children (3), } \\
\text { and significant differences between treatment and } \\
\text { control children in print composite (4) }\end{array}$ & $\begin{array}{l}\text { Calculated, no covariates d }-0.04 \\
(1 \mathrm{~A}),-0.08(1 \mathrm{~B}),-0.05(2 \mathrm{~A}),-0.23 \\
(2 \mathrm{~B}), 0.28(3 \mathrm{~A}), 0.13(3 \mathrm{~B}), 0.47 \\
(4 \mathrm{~A}), \text { and }-0.02(4 \mathrm{~B})\end{array}$ \\
\hline \multicolumn{6}{|c|}{$\begin{array}{l}\text { Design details in webappendix pp 7-15. If effect sizes were not reported we calculated a Cohen's } d \text { (d) effect sizes from either post-test means, differences from pretest to post-test means, or from ordinary least } \\
\text { squares regression results. We focused on main effects and not subgroups, unless results were only presented by subgroups. If results were only presented by subgroups, then we reported the range of the effect } \\
\text { size. We also reported the range for tests that had subscales. If studies did not report Cohen's d effect sizes, and we did not have the information to calculate them, then we reported unavailable. }\end{array}$} \\
\hline
\end{tabular}

preschool attendance ${ }^{88,89}$ and early child development, ${ }^{87,89}$ but there is a need for more robust assessments. ${ }^{86}$

\section{Programmatic implications}

Most effectiveness studies that we have reviewed reported substantial and positive effects on child development, but results from assessments of scaled-up programmes were more variable. In panel 3 we list our conclusions and recommendations for the scale-up of early child development programmes. The Wolfensohn Center at Brookings Institution assessed issues in taking early child development to scale from 2005 to 2011. ${ }^{23,90,91}$ Expanding coverage while maintaining quality is a major issue for every programme, and needs a system of capacity development. ${ }^{92}$ Scale-up efforts in Mexico and South Africa have identified that existing systems, including private ones, might be undermined when public coverage expands..$^{91,92}$ Scale-up to universal provision should include systems of governance, provisioning, and capacity building for implementation, and must include ongoing and continual advocacy. ${ }^{91}$ Monitoring methods are needed to track progress and facilitate advocacy.

Co-occurring risk factors such as stunting and lack of stimulation should be addressed together for maximum effect, such as combining nutrition, responsive child feeding, and child-stimulation interventions. ${ }^{14,15}$ Few studies have assessed which combinations work best, although several combinations exist. Combinations tend to be more effective if addressing risks that co-occur, and if the programme can coordinate interventions to minimise extra work. Adding early child development might be motivating for parents and childcare workers. Research is urgently needed on how to effectively integrate psychosocial interventions with programmes to address the risks identified in the first report of this Series. ${ }^{4}$

Reaching the poorest, a key goal for many programmes, is also a challenge. In the Philippines for example, publicly funded childcare centres exist in $86 \%$ of villages, but coverage reaches only $39 \%$ of the age-eligible population. ${ }^{90}$ A recent estimate of the cost of scaling up nutrition services noted that the unit costs were constant for $80 \%$ of the population, but were 3-4-times higher for the next $10 \%{ }^{93,94}$ Yet to reduce inequality, investments must be targeted at the poorest. Our review suggests that effects might be greater for these children, possibly resulting in a more favourable benefit-to-cost ratio.

Countries might have difficulty creating a mechanism for integrated or coordinated interventions for early child development across sectors..$^{90}$ A programme is often run by one ministry and coordination with others can be limited, even if the effects could be synergistic. Community involvement and the demand for services as well as a legal policy structure have facilitated implementation..$^{23,90-92}$ In the Philippines, for example, a legal mandate combined several delivery systems with local government control to create an integrated programme..$^{90}$ Under a controlled political system, Cuba's Educa Tu Hijo programme effectively scaled up an integrated approach and achieved virtually universal coverage of young children in early child development by $2000{ }^{23}$ Community involvement and ownership were important for its successful scale-up.

For most programmes, early child development components for younger children (aged 0-3 years) were less common than for older children. Incorporating early child development activities into the health systemthrough prenatal care, breastfeeding promotion programmes, wellchild visits, consultations for mild illnesses, parenting education, and early intervention for at-risk children-might provide the best opportunities for reaching children younger than 3 years.

\section{Estimating potential benefits of preschool}

Preschool is only one component of a comprehensive early child development agenda, but can serve as a proxy in an analysis of potential economic benefits of increasing 
Panel 3: Recommendations for development and expansion of national programmes to support early child development

\section{Maximise quality of early child development programmes}

- Maximise quality in all early child development programmes, in programme design, curriculum, childcare-provider development, monitoring and assessment, and governance and supervision

- Adapt programmes to children and families from ethnically or economically vulnerable groups

- Incorporate families and communities as active partners in the development of early child development programmes to integrate relevant child-rearing practices and cultural beliefs

\section{Promote multisectoral integration}

- Mainstream early child development into health programmes such as maternal and child health; nutrition; HIV/AIDS, malaria, and tuberculosis; mental health; violence; and injury

- Develop effective coordination mechanisms in sectors for early child development

- Develop and assess integrated strategies, packages, and approaches to early child development that are suitable for scale-up

\section{Prioritise monitoring and assessment}

- Systematically assess effectiveness of early child development interventions to establish the most effective approaches to improve quality and outcomes particularly for the most disadvantaged

- Assess relative effectiveness of various quality improvements for preschools (eg, adding more years of preschool, increasing teacher training)

- Develop and assess cost-effectiveness of new approaches for early child development promotion such as conditional cash transfer programmes with an early child development component, educational media, or other information technologies for children and families and integrated programmes

- Assess the relative effectiveness of early child development interventions for children at risk because of malnutrition, low birthweight, HIV, or disabilities

\section{Emphasise policy action}

- Use the existing theory and evidence to inform policy and decision makers at all levels that early child development is fundamental to the promotion of social justice and equity

- Build a sustainable funding mechanism for early child development services and interventions

- Acknowledge and support interventions that protect and support children and families in the first 5 years of life

\section{Panel 4: Methods for our gap analysis}

We estimated the association between the schooling gap (gap in median years of schooling between the wealthiest quintile and each of the other quintiles) and preschool enrolment by regressing the gap on the preschool gross enrolment rate 8-12 years earlier for each country with ordinary least squares in Stata 10, controlling for per head gross domestic product (GDP) in constant dollars adjusted for purchasing power and income inequality (by use of the Gini coefficient). We then calculated the projected economic gain from decreasing the schooling gap through increasing preschool enrolment as the present discounted value of added wage productivity. We estimated added wage productivity for each country using a weighted average of $8.3 \%$ for urban areas and $7.5 \%$ for rural areas for the returns to an additional year of schooling ${ }^{93}$ and average wages were based on a $40 \%$ wage share of GDP. We used discount rates of $3 \%$ and $6 \%$ to adjust (to the time at which investments in preschool enrolments are assumed to be made) future wage earnings starting 12 years after preschool enrolment and lasting 45 years. We estimated the economic benefits from increasing preschool programmes under three scenarios: moving countries with less than $25 \%$ pre-primary enrolment to $25 \%$, moving countries with less than $35 \%$ pre-primary enrolment to $35 \%$, and moving countries with less than $50 \%$ pre-primary enrolment to $50 \%$.

In table 3 we summarise these estimates for one cohort of children in 2008 US\$. Changes in preschool enrolments are simulated to induce reductions in schooling gaps based on the regression analysis discussed.

country fixed-effects and inclusion of child mortality rate as a control provide some assurance that the results are attributable to preschool enrolment, rather than the access or quality of the school and health systems.

We calculated the loss in dollars from the schooling gap and identified that the gaps between the richest quintile and the poorer quintiles within low-income and middleincome countries resulted in an estimated total loss of $\$ 196$ billion in present annual productivity due to fewer years of schooling (panel 4). Using estimates from the regression of the schooling gap on preschool enrolment, we then simulated reductions in schooling gaps due to increasing preschool enrolment rates and calculated the economic benefits of reducing the schooling gap for one cohort of children.

With a $3 \%$ discount rate, the benefits from reducing the schooling gap range from $\$ 10.6$ billion with an increase of all children in each country to $25 \%$ enrolment for 1 year of preschool, to $\$ 33.7$ billion with an increase to $50 \%$ preschool enrolment (table 3). With a $6 \%$ discount rate the benefits were $\$ 4.7$ billion (for $25 \%$ ) to $\$ 14$. 9 billion (for $50 \%$ ). These benefits, compared with the costs based on the number of additional children enrolled and the median cost of preschool per student, ${ }^{99}$ imply benefit-toobservations were available, and to the inclusion of child mortality in the fixed-effects regressions. The use of investments. We estimated the effect of presc the gap between schooling attain compared with youth in the other wealth quintiles 73 low-income and middle-income countries with a tota of 2.69 billion people (panel in preschool enrolment the schooling gap for those aged $15-19$ years declines 0.026 grades $(95 \% \mathrm{CI}-0 \cdot 14$ to $-0 \cdot 38$ figure 4). This result, which controls for a country's gross domestic product (GDP) and inequality rates (as measured by the Gini index) is robust to the use of country fixed-effects for countries where two or more 
cost ratios respectively from $6 \cdot 4$ to $17 \cdot 6$, and are similar to programme-specific estimates ${ }^{100}$ for the USA, ${ }^{101}$ Turkey, ${ }^{102}$ and Uruguay (panel 5). ${ }^{41}$

Our estimates, based on several assumptions, suggest substantial potential gains from increasing preschool attendance with very satisfactory benefit-to-cost ratios. The estimates are most likely conservative because they include only direct wage productivity benefits and many studies suggest that there would be additional benefits due to increased schooling, such as reduced crime and improved parenting. Additionally, the estimates include

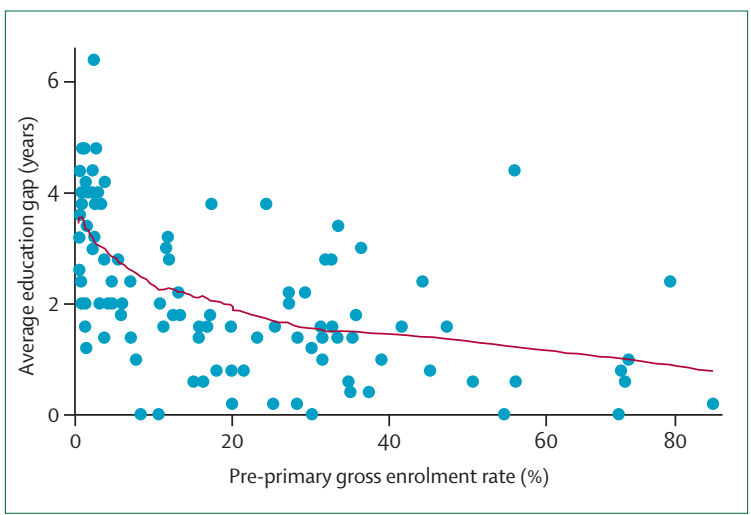

Figure 4: Association of preschool enrolment and the schooling gap for 73 low-income and middle-income countries

Schooling gap defined as the gap between schooling attainment of the wealthiest quintile of youth compared with youth in other wealth quinites. Average education gap is for those aged $15-19$ years. Pre-primary gross enrolment rate is from $8-12$ years earlier. Bandwidth $=0.8$. only preschool enrolment, and do not include parenting, nutrition and health programmes, which are also known to improve the child's school performance and therefore have economic benefits. Increased earnings are calculated assuming that GDP is not growing over time with technological change or increased capital investment; the resulting benefits would be larger if these were included.

\section{Trends in policies and funding}

In the 2007 Series, there was a call for expanded early child development programmes, policies, and coordinating mechanisms at the national level. According to UNICEF annual reports, more than 40 countries are developing or have developed and received parliamentary approval for early child development policies, and several UN bodies have publicly supported early child development. WHO's Commission on the Social Determinants of Health made child development one of its key focus areas, ${ }^{5}$ the Organization for American States issued a "hemispheric commitment" to early child development in November, 2007, ${ }^{103}$ and the Secretary General of the UN's report highlighted the rights of the child in early childhood. ${ }^{104}$

Progress has also been made on the 2007 recommendation to develop a core set of globally accepted measurements and indicators for child development that could be adapted across countries for monitoring, planning, and assessment. UNICEF supported 53 countries to prepare their own standards for what preschool children should know and be able to do.

\begin{tabular}{|c|c|c|c|c|}
\hline & Actual values & $\begin{array}{l}\text { Projected } \\
\text { values with } \\
\text { minimum } \\
\text { preschool } \\
\text { enrolment of } \\
25 \%\end{array}$ & $\begin{array}{l}\text { Projected } \\
\text { values with } \\
\text { minimum } \\
\text { preschool } \\
\text { enrolment of } \\
35 \%\end{array}$ & $\begin{array}{l}\text { Projected } \\
\text { values with } \\
\text { minimum } \\
\text { preschool } \\
\text { enrolment of } \\
50 \%\end{array}$ \\
\hline Mean preschool enrolment, 8-12 years before data for schooling gap & $17 \cdot 6 \%$ & $30 \cdot 6 \%$ & $38 \cdot 3 \%$ & $51 \cdot 1 \%$ \\
\hline $\begin{array}{l}\text { Total number of children aged } 5 \text { years enrolled, } 8-12 \text { years before data for } \\
\text { schooling gap (millions) }\end{array}$ & $11 \cdot 4$ & $19 \cdot 8$ & $24 \cdot 8$ & $33 \cdot 1$ \\
\hline Mean estimated average gap of schooling (years) & 1.9 & $1 \cdot 7$ & $1 \cdot 5$ & $1 \cdot 2$ \\
\hline \multicolumn{5}{|l|}{ Benefits due to increasing preschool enrolment } \\
\hline PDV of lifetime earnings ( $3 \%$ discount rate) for one cohort (2008 US $\$$ billions) & .. & $\$ 10 \cdot 64$ & $\$ 18 \cdot 73$ & $\$ 33 \cdot 72$ \\
\hline PDV of lifetime earnings ( $6 \%$ discount rate) for one cohort ( $\$$ billions) & .. & $\$ 4.73$ & $\$ 8.32$ & $\$ 14.97$ \\
\hline Total costs due to increasing preschool enrolment ( $\$$ billions) & .. & $\$ 0.74$ & $\$ 1 \cdot 18$ & $\$ 1.92$ \\
\hline \multicolumn{5}{|l|}{ Benefit-to-cost ratios } \\
\hline $3 \%$ discount rate & .. & $14 \cdot 3$ & $15 \cdot 8$ & $17 \cdot 6$ \\
\hline $6 \%$ discount rate &.. & $6 \cdot 4$ & $7 \cdot 0$ & $7 \cdot 8$ \\
\hline \multicolumn{5}{|c|}{$\begin{array}{l}\text { Our sample consists of } 73 \text { countries with a population of about } 3 \text { billion with preschool data from } 1998-2007 . \text { We dropped Bangladesh, Namibia, and Tanzania from our } \\
\text { sample because of inconsistent statistics in the preschool enrolment rates. The schooling gap is the gap in median years of schooling between the wealthiest quintile and } \\
\text { each of the other quintiles for individuals } 15-19 \text { years old. }{ }^{95} \text { The benefits due to increasing enrolment were calculated with estimates from an ordinary least squares (OLS) } \\
\text { regression of average schooling gap on preschool enrolment from } 8 \text { to } 12 \text { years before the schooling gap statistic, }{ }^{96} \text { gross domestic product per capita, and Gini. }{ }^{97} \text { Estimates } \\
\text { from OLS regression were used to simulate the schooling gap under three scenarios with preschool enrolment floors of } 25 \%, 35 \% \text {, and } 50 \% \text {. The economic benefit from } \\
\text { decreasing the schooling gap through increasing preschool enrolment was calculated as the present discounted value (PDV) of added wage productivity under the } \\
\text { assumption that earnings are zero for first } 12 \text { years after preschool and then are equal to yearly average earnings incremented by the average rates of return to schooling for } \\
\text { the subsequent } 45 \text { years. For the benefit-to-cost ratio, we used the median cost per preschool student in } 2004 \text { from UNESCO data on } 38 \text { low-income and middle-income } \\
\text { countries (US } \$ 77.50) \text { adjusted to show the } 2008 \text { values ( } \$ 88.34) \text {. }\end{array}$} \\
\hline
\end{tabular}




\section{Panel 5: Conclusions from our gap analysis}

A conservative estimate of the returns to investment in early child development is illustrated by the effects of improving one component, preschool attendance. Achieving enrolment rates of $25 \%$ per country in 1 year would result in a benefit of US $\$ 10.6$ billion and achieving $50 \%$ preschool enrolment could have a benefit of more than $\$ 33$ billion (in terms of the present discounted value of future labour market productivity) with a benefit-to-cost ratio of 17.6 . Incorporating improved nutrition and parenting programmes would result in a larger gain.

The 2010 UNICEF Multiple Indicator Cluster Survey includes both the Family Care Indicators and an assessment of child development for children aged 3-4 years. Several regional child development assessments are also being developed.

Policies and indicators are effective only if funding is available. Because of increased awareness of neurological, economic, and behavioural science findings in recent years, donor interest is increasing but the results for funding are mixed. Organisations such as Save the Children, UNICEF, The World Bank, and the Interamerican Development Bank are providing funds. Corporations are new entrants, sponsoring modest programmes, principally in regions where they have business interests. Centre-based and school-based preschool programming continues to predominate, and interest in the $0-3$ years age-group is growing. The complexity, cost, and need for multisectoral ownership of early child development programmes continues to be a constraint and the role of early child development in future global agendas such as new Millennium Development Goals needs to be strengthened.

Governments are not allocating enough funds to early child development programmes. A report from the Organisation for Economic Co-operation and Development (OECD) estimated that a public investment of $1 \%$ of GNP is the minimum required to ensure provision of quality early child development services. ${ }^{105,106}$ Average government spending for children aged 0-6 years across OECD countries was $2 \cdot 36 \%$ of GNP. ${ }^{106}$ Public spending on preschool is at least $0.4 \%$ in some central and eastern European and Latin American countries (Belarus, Chile, Costa Rica, Croatia, Guyana, Mexico, and Mongolia, whereas governments of Kenya, Nepal, and Tajikistan spend just $0 \cdot 1 \%$ of GNP and Nicaragua and Senegal spend less than $0.02 \%$ of GNP on preschool education (data were not available on any other early child development services). ${ }^{105}$ In most countries, less than $10 \%$ of the education budget is allocated to preschool education. ${ }^{106}$ Unless governments allocate more resources to quality early child development programmes for the poorest segment of the population, economic disparities will continue to exist and to widen.

\section{Conclusions and future work}

We have presented evidence for factors contributing to the effectiveness of interventions to promote early child development in low-income and middle-income countries (panel 2), recommendations for how programmes and policies can support early child development (panel 3), and we pose several future research questions (panel 6). The review from the previous Series ${ }^{3}$ reported that the most effective early child development programmes are those that provide direct learning experiences for children and their families, are high intensity, targeted towards younger and more disadvantaged children, are integrated with other systems such as nutrition or family support, and are of long duration. These conclusions are supported by our present review, although we have also identified some beneficial effects with more moderate-length interventions. We have also highlighted the importance of programme quality on effectiveness.

In this review, all parenting education effectiveness trials positively affected parenting behaviour, children's development, or both, but only half of the scaled-up programmes showed similar effects. The most effective interventions were those with systematic training of workers, a structured and evidence-based curriculum, and

Panel 6: Future research questions

- What factors increase effectiveness of parenting programmes?

- How can pregnant women be included in parenting interventions in preparation for raising children?

- How can maternal mental health interventions effectively incorporate child development?

- How can preschool be made most effective in low-income and middle-income countries?

- What is the optimum timing, duration, and exposure to preschool?

- How can preschools be integrated with other services-eg, by offering age-appropriate health services and nutrition programmes?

- What are the additional effects of improving the transition to primary school, and primary school quality, on child development outcomes?

- What are the most effective approaches for combining nutrition and psychosocial programmes at scale, and for which children?

- What interventions are most effective for children with disabilities or children at risk in low-resource settings?

- How can conditional cash transfer programmes be most effectively combined with programmes to support a young child's development and nutrition?

- What possibilities exist for increasing use of media, such as television, radio, and mobile telephones for improving parenting and child outcomes?

- What strategies can be used to increase funding for young children's growth and development? 
opportunities for parental practice with children with feedback. Community and family involvement was also effective. Preschool attendance in most cases had a positive effect on learning, but improvements in preschool quality were more consistently effective. Promising interventions include linking early child development services to conditional cash transfer programmes and developing educational media for children and parents. There is suggestive, but restricted, evidence that psychosocial interventions can improve the wellbeing of children at risk because of physical disabilities, severe malnutrition, low birthweight, and HIV infection. To illustrate the economic effect of early child development interventions, we developed a simulation showing a benefit of $\$ 10.6$ billion for increasing preschool enrolment to $25 \%$ in all countries, and $\$ 33.7$ billion for increasing to $50 \%$, with a benefit-to-cost ratio as large as 17.6 to 1 . Based on our review and economic simulation, we conclude that early child development interventions are a good investment for reducing inequalities in the development of children's potential perpetuated by poverty, poor health, poor nutrition, and restricted learning opportunities.

\section{Contributors}

All authors participated in the review of published work, and drafting and review of the report. PLE and LCHF are the lead authors. All authors reviewed and provided commentary on the text. Reviews and drafting of individual topics were as follows: economic issues $\mathrm{HA}, \mathrm{JB}$, and $\mathrm{MH}$; parenting PLE and LCHF; preschool CO'G, LCHF, and PLE; media PLE; conditional cash transfers LCHF; disabilities and high-risk AY and IE; political and social context MCdeM, NU, and SI. The steering committee of the Global Child Development Group coordinated the writing of the report in this Series.

\section{Conflicts of interest}

We declare that we have no conflicts of interest.

\section{Acknowledgments}

We thank Kallista Bley for help in document preparation, Santiago Cueto for Young Lives data, Ivelina Borisova for document searches and reviews, and Giorgio Tamburlini for a critical review of the report. Members of the Steering Committee (Sally Gratham-McGregor, Susan Walker, Ted Wachs, Maureen Black) have reviewed all drafts extensively. A meeting of all authors to discuss review findings and coordinate the report was held in Jamaica in December, 2009, with the support of the Global Alliance for Improved Nutrition (GAIN), UNICEF, the Bernard van Leer Foundation, and the University of the West Indies. A follow-up steering committee meeting was held in May, 2010, with the support of UNICEF, the Bernard van Leer Foundation, and the Child Health and Nutrition Research Initiative. The sponsors had no role in the design and conduct of the review, interpretation and writing, or the decision to submit for publication. We thank the Global Child Development Group Secretariat for coordinating the meetings.

\section{References}

1 Grantham-McGregor S, Cheung YB, Cueto S, et al. Developmental potential in the first 5 years for children in developing countries. Lancet 2007; 369: 60-70.

2 Walker SP, Wachs TD, Gardner JM, et al. Child development: risk factors for adverse outcomes in developing countries. Lancet 2007; 369: 145-57.

3 Engle PL, Black MM, Behrman JR, et al. Strategies to avoid the loss of developmental potential in more than 200 million children in the developing world. Lancet 2007; 369: 229-42.

4 Walker SP, Wachs TD, Grantham-McGregor SM, et al. Inequality in early childhood: risk and protective factors for early child development. Lancet 2011; published online Sept 23. DOI:10.1016/ S0140-6736(11)60555-2.
5 Commission on Social Determinants of Health. Closing the gap in a generation: health equity through action on the social determinants of health-final report of the Commission on Social Determinants of Health. Geneva: World Health Organization, 2008.

6 Vegas E, Santibanez L. The promise of early child development in Latin America and the Caribbean. Washington, DC: The World Bank, 2010.

7 Dunn LM, Padilla ER, Lugo DE, Dunn LM. Test de Vocabulario en Imágenes Peabody (Peabody Picture Vocabulary Test): Adaptación Hispanoamericana (Hispanic-American Adaptation). Circle Pines, MN: American Guidance Service (Dunn Educational Services), 1986.

8 Cueto S, Leon J, Guerrero G, Muñoz I. Psychometric characteristics of cognitive development and achievement instruments in Round 2 of Young Lives-Technical Note 15. Oxford: Department of International Development, 2009

9 Bhutta ZA, Ahmed T, Black RE, et al. What works? Interventions for maternal and child undernutrition and survival. Lancet 2008 ; 371: 417-40.

10 Nores M, Barnett WS. Benefits of early childhood interventions across the world: (under) investing in the very young. Econ Educ Rev 2010; 29: 271-82

11 Maulik PK, Darmstadt GL. Community-based interventions to optimize early childhood development in low resource settings. J Perinatol 2009; 29: 531-42.

12 McMaster University School of Nursing. Effective public health practice project: quality assessment tool for quantitative studies. http://www.hamilton.ca/NR/rdonlyres/6b3670ac-8134-4f76-a64c9c39dbc0f768/0/qatool.pdf (accessed March 16, 2011).

13 Yarbrough DB, Shulha LM, Hopson RK, Caruthers FA. The program evaluation standards: a guide for evaluators and evaluation users, 3rd edn. Thousand Oaks, CA: Sage, 2011.

14 Aboud FE, Akhter S. A cluster-randomized evaluation of a responsive stimulation and feeding intervention in Bangladesh. Pediatrics 2011; 127: e1191-97.

15 Bentley ME, Vazir S, Engle PL, et al. A home-based educational intervention to caregivers in south India to improve complementary feeding and responsive feeding, and psychosocial stimulation increases dietary intake, growth and development of infants. FASEB J 2010; 24 (suppl): 564.14.

16 Cooper PJ, Tomlinson M, Swartz L, et al. Improving quality of mother-infant relationship and infant attachment in socioeconomically deprived community in South Africa: randomised controlled trial. BMJ 2009; 338: b974.

17 Klein PS, Rye H. Interaction-oriented early intervention in Ethiopia: the MISC approach. Infants and Young Children 2004; 17: 340-54.

18 Jin X, Sun Y, Jiang F, Ma J, Morgan C, Shen X. "Care for Development" intervention in rural China: a prospective follow-up study. J Dev Behav Pediatr 2007; 28: 213-18.

19 Leung C, Sanders MR, Leung Sl, Mak R, Lau J. An outcome evaluation of the implementation of the Triple P-Positive Parenting Program in Hong Kong. Fam Process 2003; 42: 531-44.

20 Ertem IO, Atay G, Bingoler BE, Dogan DG, Bayhan A, Sarica D. Promoting child development at sick-child visits: a controlled trial. Pediatrics 2006; 118: e124-31.

21 Kagitcibasi C, Sunar D, Bekman S, Baydar N, Cemalcilar Z. Continuing effects of early enrichment in adult life: the Turkish Early Enrichment Project 22 years later. J Appl Dev Psychol 2009, 30: 764-79.

22 Janssens W, Rosemberg C. The impact of a home-visiting Early Childhood intervention in the Caribbean on cognitive and socio-emotional child development. Amsterdam: Amsterdam Institute for International Development, 2011.

23 Tinajero A. Scaling-up early child development in Cuba-Cuba's Educate Your Child Program: strategies and lessons from the expansion process. Washington, DC: The Brookings Institution, 2010. http://www.brookings.edu/papers/2010/04_child_ development_cuba_tinajero.aspx (accessed Aug 29, 2011).

24 Al-Hassan S, Lansford J. Evaluation of the Better Parenting Program in Jordan. Early Child Dev Care 2011; 181: 587-98.

25 Palti H, Zilber N, Kark SL. A community-orientated early intervention programme integrated in a primary preventive child health service-evaluation of activities and effectiveness. Community Med 1982; 4: 302-14.
For more on the Global Child Development Group see http:// www.globalchilddevelopment.org 
26 Engle PL, Smeby A, Grover D. Care for development in three central Asian countries: report of process evaluation in Tajikistan, Kyrgyzstan, and Kazakhstan. http://globalchilddevelopment.com/ sites/default/files/Status\%20of\%20Care\%20for\%20 Development\%20in\%20three\%20Central\%20Asian\%20 Countries\%20Oct\%2031\%202010.doc (accessed Aug 29, 2011).

27 Nodira A, Yakupov S, Yakupov T. Impact Assessment Family Education Project. Tashkent: Sharh va Tavsiya Sociology Centre, 2009.

28 Sidibeh L. Evaluation of the parental education programme at LRR, CRR \& URR, The Gambia. http://globalchilddevelopment.com/ sites/default/files/Gambia\%20ECD\%20PARENTAL\%20 EDUCATION\%20PROGRAMME\%20EVALUATION\%20final\%20 final.doc (accessed Aug 29, 2011).

29 Bradley RH, Corwyn RF. Caring for children around the world: a view from HOME. Int J Behav Dev 2005; 29: 468-78.

30 Walker S. Promoting equity through early child development interventions for children from birth through three years of age. In: Alderman H, ed. No small matter. Washington, DC: The World Bank, 2011: 115-54.

31 WHO. Documents on integrated management of childhood illness listed by year of publication. Geneva: World Health Organization, 2010. http://www.who.int/child_adolescent_health/documents/imci/ en/index.html (accessed Aug 29, 2011).

32 Nowak C, Heinrichs N. A comprehensive meta-analysis of triple P-positive parenting program using hierarchical linear modeling: effectiveness and moderating variables. Clin Child Fam Psychol Rev 2008; 11: 114-44.

33 Moran P, Ghate D. The effectiveness of parenting support. Children and Society 2005; 19: 329-36.

34 Korfmacher J, Green B, Spellman M, Thornberg KR. The helping relationship and program participation in early childhood home visiting. Infant Ment Health J 2007; 28: 459-80.

35 Bakermans-Kranenburg MJ, van IJzendoorn MH, Juffer F. Less is more: meta-analyses of sensitivity and attachment interventions in early childhood. Psychol Bull 2003; 129: 195-215.

36 Paul D, Bhatia N, Priscilla S, Siwach S. Report of the pre-test study: Mother and Child Protection Card. New Delhi: National Institute of Public Cooperation and Child Development, 2005.

37 Aboud FE, Hossain K, O'Gara C. The Succeed Project: challenging early school failure in Bangladesh. Rese Comp Int Educ 2008; 3: 295-307.

38 Mwaura PAM, Sylva K, Malmberg L-E. Evaluating the Madrasa preschool programme in east Africa: a quasi-experimental study. Int J Early Years Educ 2008; 16: 237-55.

39 Raine A, Mellingen K, Liu J, Venables P, Mednick SA. Effects of environmental enrichment at ages 3-5 years on schizotypal personality and antisocial behavior at ages 17 and 23 years. Am J Psychiatry 2003; 160: 1627-35.

40 Urzua S, Veramendi G. The impact of out-of-home childcare centers on early childhood development. Washington, DC: Inter-American Development Bank, 2010.

41 Berlinski S, Galiani S, Manacorda M. Giving children a better start: preschool attendance and school-age profiles. J Public Econ 2008; 92: $1416-40$.

42 Bernal R, Fernandez C, Flores CE, et al. Evaluación de impacto del Programa Hogares Comunitarios de Bienestar del ICBF (evaluation of the impact of the program of community homes of well-being of ICBF). Bogota: Centro de Estudios sobre Desarrollo Económico Universidad de los Andes, 2009.

43 Aboud FE, Hossain K. The impact of preprimary school on primary school achievement in Bangladesh. Early Child Res Q 2011; 26: $237-46$.

44 Baker-Henningham H, Walker S, Powell C, Gardner JM. A pilot study of the Incredible Years Teacher Training programme and a curriculum unit on social and emotional skills in community pre-schools in Jamaica. Child Care Health Dev 2009; 35: 624-31.

45 Malmberg L-E, Mwaura P, Sylva K. Effects of a preschool intervention on cognitive development among East-African preschool children: a flexibly time-coded growth model. Early Child Res Q 2011; 26: 124-33.

46 Moore AC, Akhter S, Aboud FE. Evaluating an improved quality preschool program in rural Bangladesh. Int J Educ Dev 2008; 28: $118-31$
47 Morris E, Philip M, Othman AF, Mitchell J. Radio Instruction to Strengthen Education (RISE) in Zanzibar: impact study. Boston: Education Development Center, Inc, and USAID, 2009.

48 Opel A, Ameer SS, Aboud FE. The effect of preschool dialogic reading on vocabulary among rural Bangladeshi children. Int J Educ Res 2009; 48: 12-20.

49 Rao N, Pearson V, Sun J, Pearson E, Constas M, Engle PL. Is something better than nothing? An evaluation of early childhood programs in Cambodia. Child Dev (in press).

50 Rao N, Sun J, Zhou J, Zhang L. Early achievement in rural China: the role of preschool experience. Early Child Res $Q$ (in press).

51 Rolla San Francisco A, Arias M, Villers R, Snow C. Evaluating the impact of different early literacy interventions on low-income Costa Rican kindergarteners. Int J Educ Res 2006; 45: 188-201.

52 Berlinski S, Galiani S, Gertler P. The effect of pre-primary education on primary school performance. J Public Econ 2009; 93: 219-34.

53 Mwaura PAM, Sylva K, Malmberg L. Evaluating the Madrasa preschool programme in east Africa: a quasi-experimental study. Int J Early Years Educ 2008; 16: 237-55.

54 Ho J, Thukral H. Tuned in to student success: assessing the impact of interactive radio instruction for the hardest-to-reach. J Educ Int Dev 2009; 4: 34-51.

55 Handa S, Davis B. The experience of conditional cash transfers in Latin America and the Caribbean. Dev Policy Rev 2006; 24: 513-36.

56 Fiszbein A, Schady N, Ferreira FHG, et al. Conditional cash transfers: reducing present and future poverty. Washington DC: The World Bank, 2009.

57 Das J, Do Q-T, Özler B. Reassessing conditional cash transfer programs. World Bank Res Obs 2005; 20: 57-80.

58 de Janvry A, Sadoulet E. Making conditional cash transfer programs more efficient: designing for maximum effect of the conditionality. World Bank Econ Rev 2006; 20: 1-29.

59 Rawlings LB, Rubio GM. Evaluating the impact of conditional cash transfer programs. World Bank Res Obs 2005; 20: 29-55.

60 Fernald LCH, Gertler PJ, Neufeld LM. 10-year effect of Oportunidades, Mexico's conditional cash transfer programme, on child growth, cognition, language, and behaviour: a longitudinal follow-up study. Lancet 2009; 374: 1997-2005.

61 Fernald LCH, Gertler PJ, Neufeld LM. Role of cash in conditional cash transfer programmes for child health, growth, and development: an analysis of Mexico's Oportunidades. Lancet 2008; 371: 828-37.

62 Macours K, Schady N, Vakis R. Cash transfers, behavioral changes, and the cognitive development in early childhood: evidence from a randomized experiment. Am Econ J Appl Econ (in press).

63 Fernald LCH, Hidrobo M. Ecuador's cash transfer program (Bono de Desarollo Humnano) and child development in infants and toddlers: a randomized effectiveness trial. Soc Sci Med 2011; 72: 1437-46.

64 Paxson C, Schady N. Does money matter? The effects of cash transfers on child health and development in rural Ecuador. Econ Dev Cult Change 2010; 59: 187-229.

65 Fisch SM. Children's learning from educational television: Sesame Street and beyond. Mahwah, NJ: Lawrence Erlbaum Associates Inc, 2004.

66 Anderson DR, Pempek TA. Television and very young children. Am Behav Sci 2005; 48: 505-22.

67 Baydar N, Kagitçibasi Ç, Küntay AC, Göksen F. Effects of an educational television program on preschoolers: variability in benefits. J Appl Dev Psychol 2008; 29: 349-60.

68 Lee J. The educational impact of Sisimpur: results of an experimental study of children's learning. http://comminit.com/ early-child/node/70718 (accessed Aug 24, 2011).

69 Jain S, Kibria N. Sisimpur, Sesame Street in Bangladesh: exploring the challenges in early childhood development. J Child Media 2009; 3: 95-100.

70 King E, De Silva M, Stein A, Patel V. Interventions for improving the psychosocial well-being of children affected by HIV and AIDS. Cochrane Database Syst Rev 2009; 2: CD006733.

71 Cole C, Labin D, del Rocio Galarza M. Begin with the children: what research on Sesame Street's international co-productions reveals about using media to promote a new more peaceful world. Int J Behav Dev 2008; 32: 359-65. 
72 McConachie H, Huq S, Munir S, Ferdous S, Zaman S, Khan NZ. A randomized controlled trial of alternative modes of service provision to young children with cerebral palsy in Bangladesh. J Pediatr 2000; 137: 769-76.

73 Finkenflügel H, Wolffers I, Huijsman R. The evidence base for community-based rehabilitation: a literature review. Int J Rehabil Res 2005; 28: 187-201.

74 Mirza I, Tareen A, Davidson LL, Rahman A. Community management of intellectual disabilities in Pakistan: a mixed methods study. J Intellect Disabil Res 2009; 53: 559-70.

75 Ashworth A, Khanum S, Jackson A, Schofield C. Guidelines for the inpatient treatment of severely malnourished children. Geneva: World Health Organization, 2003.

76 Nahar B, Hamadani JD, Ahmed T, et al. Effects of psychosocial stimulation on growth and development of severely malnourished children in a nutrition unit in Bangladesh. Eur J Clin Nutr 2009; 63: 725-31.

77 Jones L, Morris J, Berrino A, Crow C, Jordans M, Okema L. Does combining infant stimulation with emergency feeding improve psychosocial outcomes for displaced mothers and babies? A controlled evaluation from Northern Uganda. Am J Orthopsychiatry (in press).

78 Ramey CT, Bryant DM, Wasik BH, Sparling JJ, Fendt KH, La Vange LM. Infant health and development program for low birth weight, premature infants: program elements, family participation, and child intelligence. Pediatrics 1992; 89: 454-65.

79 Klebanov P, Brooks-Gunn J. Cumulative, human capital, and psychological risk in the context of early intervention: links with IQ at ages 3, 5, and 8. Ann NY Acad Sci 2006; 1094: 63-82.

80 Spittle A, Orton J, Doyle LW, Boyd R. Early developmental intervention programs post hospital discharge to prevent motor and cognitive impairments in preterm infants. Cochrane Database Syst Rev 2007; 2: CD005495.

81 Moster D, Lie RT, Markestad T. Long-term medical and social consequences of preterm birth. N Engl J Med 2008; 359: 262-73.

82 Walker SP, Chang SM, Younger N, Grantham-McGregor SM. The effect of psychosocial stimulation on cognition and behaviour at 6 years in a cohort of term, low-birthweight Jamaican children. Dev Med Child Neurol 2010; 52: e148-54.

83 Nair MK, Philip E, Jeyaseelan L, George B, Mathews S, Padma K. Effect of Child Development Centre model early stimulation among at risk babies-a randomized controlled trial. Indian Pediatr 2009; 46 (suppl): s20-26.

84 Wallander JL, McClure E, Biasini F, et al. Brain research to ameliorate impaired neurodevelopment--home-based intervention trial (BRAIN-HIT). BMC Pediatr 2010; 10: 27.

85 UNAIDS. Global report: UNAIDS report on the global AIDS epidemic 2010. Geneva: Joint United Nations Programme on HIV/AIDS, 2010. http://www.unaids.org/en/media/unaids/ contentassets/documents/unaidspublication/2010/20101123 globalreport_en.pdf (accessed March 13, 2011).

86 Schenk K. Community interventions providing care and support to orphans and vulnerable children: a review of evaluation evidence. AIDS Care 2009; 21: 918-42.

87 Potterton J, Stewart A, Cooper P, Becker P. The effect of a basic home stimulation programme on the development of young children infected with HIV. Dev Med Child Neurol 2010; 52: 547-51.

88 Nyesigomwe L. Strengthening the capacity of grandmothers in providing care to young children affected by HIV/AIDS J Intergener Relatsh 2006; 4: 55-63.

89 Lusk D. Bungoma and Vihiga annual assessments: key results. Washington, DC: Academy for Educational Development, 2005.
90 Wolfensohn Center for Development at Brookings. Scaling up early child development in the developing world: event summary. Washington, DC: Wolfensohn Center for Development at Brookings, 2009. http://www.brookings.edu/ /media/Files/ events/2009/0505_early_child_development/20090505_early_child_ development_summary.pdf (accessed Aug 24, 2011).

91 Biersteker L. Scaling-up early child development in South Africa: introducing a reception year (grade R) for children aged five years as the first year of schooling. Washington, DC: The Brookings Institution, 2010. http://www.brookings.edu/papers/2010/04_child_ development_south_africa_biersteker.aspx (accessed Aug 29, 2011).

92 Yosikawa H, McCartney K, Myers R, et al. Early childhood education in Mexico: expansion, quality improvement, and curricular reform. Florence: Innocenti Research Center, 2007.

93 Orazem P, Glewwe P, Patrinos H. Copenhagen Consensus 2008 Challenge Paper: education. http://www.copenhagenconsensus. com/The\%2010\%20challenges/Education-1.aspx (accessed Aug 24, 2011)

94 Horton S, Shekar M, McDonald CM, Mahal A, Brooks JK. Scaling up nutrition: what will it cost? Washington, DC: The World Bank, 2009.

95 Filmer D. Education attainment and enrollment around the world. http://econ.worldbank.org/projects/edattain (accessed Aug 5, 2010).

96 Filmer, D. Education attainment and enrollment around the world: an international database. Washington, DC: The World Bank, 2010. http://econ.worldbank.org/projects/edattain (accessed Aug 24, 2011).

97 The World Bank. Education statistics. http://go.worldbank.org/ ITABCOGIV1 (accessed Aug 24, 2011).

98 The World Bank. World development indicators. http://data. worldbank.org/indicator (accessed Aug 24, 2011).

99 UNESCO. Education for all global monitoring report 2007: strong foundations, early childhood care and education. Paris: UNESCO Publishing, 2006.

100 Kilburn MR, Karoly LA. The economics of early childhood policy: what the dismal science has to say about investing in children. Santa Monica, CA: RAND Corporation, 2008. http://www.rand. org/pubs/occasional_papers/2008/RAND_OP227.pdf (accessed Nov 15, 2011).

101 Reynolds AJ, Temple JA. Cost-effective early childhood development programs from preschool to third grade. Annu Rev Clin Psychol 2008; 4: 109-39.

102 Kaytaz M. A cost benefit analysis of preschool education in Turkey. http://www.acev.org/arastirmalarimiz.php?id=24\&lang=en\&page=3 (accessed Aug 24, 2011).

103 Organization of American States, Inter-American Council for Integral Development. Draft "hemispheric commitment to early childhood education and joint agenda of work (2007-2009)". Fifth Meeting of Ministers of Education; Cartagena de Indias, Colombia; Nov 15-16, 2007.

104 UN Secretary-General. Status of the Convention on the Rights of the Child-A/65/206. New York, NY: United Nations, 2010: 2-17.

105 Nadeau S, Kataoka N, Valerio A, Neumann MJ, Elder LK. Investing in young children: an early childhood development guide for policy dialogue and project preparation. Washington, DC: The World Bank; 2010. http://siteresources.worldbank.org/INTCY/ Resources/395766-1187899515414/Note-Investing_Countrys_CY_ Aug_2010.pdf (accessed Nov 15, 2010).

106 Tayler C, Bennett J. Starting strong II: early childhood education and care. Paris: Education Directorate of the Organisation of Economic Co-operation and Development, 2006. 